\title{
ASUPRA EXISTENȚEI ȘI UTILITĂȚII \\ DREPTULUI NATURAL: EVOLUȚIA UNUI \\ CONCEPT
}

DOI: 10.24193 /SUBBiur.65(2020).4.30

Data publicării online:

16.03 .2021

\section{Cristina TOMULET*}

Rezumat: În această lucrare, am abordat conceptul de drept natural, pornind de la analiza unora dintre primele definiții ale sale elaborate de Cicero. Avansând spre istoria recentă, am demonstrat utilitatea acestui concept în contextul confruntării cu sisteme juridice specifice regimurilor dictatoriale. În continuare, am prezentat argumente care demonstrează existența dreptului natural și i-am precizat conținutul, făcând referire la principiile generale care îl compun și care fundamentează dreptul pozitiv, și la importanța sa în ce privește respectarea drepturilor fundamentale. În ultima parte a acestei lucrări, am analizat confruntarea dintre curentul iusnaturalist și pozitivismul juridic în scopul de a sublinia și mai clar trăsăturile dreptului natural. Nu în ultimul rând, am subliniat importanța de a opta la nivel de mentalitate juridică pentru curentul iusnaturalist în vederea prevenirii sau eradicării unor sisteme juridice vădit contrare dreptului natural.

Cuvinte-cheie: drept natural; dreptate; drept pozitiv; stat de drept; revoluție; totalitarism; iunsaturalism; pozitivism juridic.

* Asist. univ., Facultatea de Drept, Universitatea Babeş-Bolyai din Cluj, cristina.tomulet@law.ubbcluj.ro.

\section{6}




\title{
ON THE EVOLUTION OF NATURAL LAW
}

\begin{abstract}
In this article, I approached the concept of natural law, starting with the analysis of some of its first definitions developed by Cicero. Moving toward recent history, I demonstrated the usefulness of this concept in the context of dealing with legal systems specific to dictatorial regimes. Next, I presented arguments proving the existence of natural law and I determined its content, referring to the general principles included in it, which underpin positive law, and to its importance in terms of ensuring respect for fundamental rights. In the final part of this article, I analyzed the confrontation between jusnaturalism and legal positivism in order to highlight even more clearly the features of natural law. Last but not least, I stressed the importance of choosing a jusnaturalistic legal mindset in order to prevent and fight against legal systems that are manifestly contrary to natural law.
\end{abstract}

Keywords: natural law; justice; positive law; rule of law; revolution; totalitarianism; jusnaturalism; legal positivism. 
Cuprins

I. Introducere. Dificultatea definirii dreptului natural............................. 1009

II. Dreptul natural. Origine și definiții.................................................... 1010

III. $\quad$ Argumente care demonstrează existența dreptului natural .................. 1018

IV. Continutul dreptului natural ....................................................... 1024

A. Legătura dintre dreptul natural și drepturile fundamentale ale omului 1024

B. Protecția drepturilor individuale - principiu fundamental de drept natural 1026

C. Particularizarea treptată a principiului protecției drepturilor individuale 1028

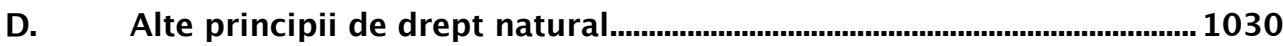

V. Legătura dintre dreptul natural și dreptul penal ................................. 1036

VI. Drept natural vs. drept pozitiv ................................................... 1042

A. Trăsăturile dreptului natural în lumina conflictului cu dreptul pozitiv 1043

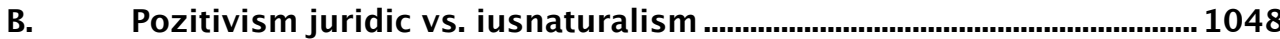

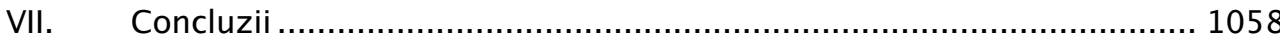




\section{Introducere. Dificultatea definirii dreptului natural}

Deși atât de important pentru definirea dreptului, dreptul natural este aproape imposibil de definit ${ }^{1}$. Aceasta este principala acuzație adusă dreptului natural de către pozitiviști. Dificultatea definirii sale se datorează faptului că dreptul natural nu este un concept pur intelectual, ci face parte din categoria intuițiilor primare și a valorilor. Dreptul natural este greu de pus în cuvinte și totuși este vizibil peste tot. În acest sens, s-a afirmat că noțiunile generale și abstracte, valorile spiritului, dreptatea nu pot fi limitate prin definiții deoarece o definițe le-ar trunchia sensul².

Aceasta nu înseamnă că în cuprinsul acestei lucrări nu vom încerca clarificarea cât mai detaliată a conținutului dreptului natural, prezentând atât definiții formulate de alții, cât și definiții proprii. Cu toate acestea, dreptul natural poate fi sesizat mult mai ușor atunci când este violat de dreptul pozitiv. De aceea, definirea sa implicită, prin raportare la conflictul dintre dreptul pozitiv şi dreptul natural, este mult mai adecvată decât definirea sa explicită. În acest sens, o secţiune ulterioară va fi dedicată trăsăturilor dreptului natural reliefate în urma conflictului dintre acesta și dreptul pozitiv.

\footnotetext{
${ }^{1}$ Prevenim în acest sens cititorul că deşi vom prezenta mai multe definiții ale dreptului natural în cuprinsul acestei secțiuni, o definire exhaustivă a acestuia este imposibilă. A încerca să definești dreptul natural seamănă cu a încerca să definești dreptatea. Or, dreptatea nu se poate defini; ea este percepută de om cu un instrument mult mai profund decât gândirea, care nu funcționează în planul definițiilor.

2 I. N. Lungulescu, Drept și dreptate, Fundația pentru Literatură şi Artă «Regele Carol II», Bucureşti, 1938, p. 15-16. Acelaşi autor sesizează că imposibilitatea de a defini dreptatea creează tendința de a exprima mai ușor dreptul sub formă negativă decât pozitivă. În acest sens, este interesant de observat că regulile de drept, în specificitatea lor, sunt interdicții. Este mai ușor să se determine ce nu este drept decât ceea ce este drept.
}

\section{9}




\section{Dreptul natural. Origine și definiții}

Dreptul natural este forma cea mai abstractă a dreptului şi stă la originea dreptului pozitiv manifestat prin izvoare.

Originea sa a fost atribuită divinității, care a întipărit preceptele de drept natural în conștiința și natura omenească3. În acest sens, s-a susţinut că dreptul natural nu este fapta omului, iar acesta nu poate fi schimbat ${ }^{4}$ decât odată cu natura omenească5

Fără a trece în revistă toate formele în care a fost conceput dreptul natural de-a lungul istoriei ${ }^{6}$, ne vom concentra doar asupra a două definiții ale acestuia: una aparținând Antichității și una de dată mai recentă, apărută în perioada de după cel de-Al Doilea Război Mondial.

Cicero este considerat ca fiind unul dintre primii filosofi care a expus o teorie a dreptului natural7. În lucrarea sa „Despre legi”, el își propune să stabilească principiile legii universale și eterne, a cărei origine precede cursul nemărginit al veacurilor și care există dinainte de apariția legiferărilor pozitive şi a constituirii guvernelor politice9. Filosoful derivă principiile

\footnotetext{
${ }^{3}$ A.P. D'Entrèves, Natural Law - An Introduction to Legal Philosophy, Hutchinson University Library, London, 1951, p. 52, I. N. Lungulescu, Drept și dreptate (precit.), p. 88, p. 108, p. 121. ${ }^{4}$ Prin absurd.

${ }^{5}$ Tr. Pop, Curs de criminologie, Institutul de Arte Grafice „Ardealul”, Cluj, 1928, p. 52.

${ }^{6}$ În acest sens, a se vedea A.P. D'Entrèves, Natural Law - An Introduction to Legal Philosophy (precit.), p. 20-34.

${ }^{7}$ R. L. Hunt, Natural Law v. Positive Law: Interpreting Morality, New England Law Review, Vol. 28, 1993, p. 248.

${ }^{8}$ M. T. Cicero, Treatise on the Laws [51 BC], (https://oll.libertyfund.org/titles/cicero-treatiseon-the-laws - site accesat în data de 20.04.2020).

${ }^{9}$ Idem, p. 24.
} 
justiției din principiile naturii, considerând că natura este temelia justiției ${ }^{10}$. Totodată, el afirmă că este o extravaganță absurdă ideea potrivit căreia toate cele stabilite prin intermediul legilor civile și a instituțiilor omenești sunt în mod necesar juste. Sunt legile tiranilor juste doar pentru că sunt legi? ${ }^{11}$ Dacă ar fi aşa, totul s-ar rezuma la obținerea voturilor și a puterii pentru a legaliza corupția și jaful ${ }^{12}$.

În acelaşi timp, Cicero evidențiază legătura dintre preceptele dreptului natural şi instrumentele interioare apte să le sesizeze: „,(..) nu avem nicio altă regulă aptă să distingă între o lege bună şi una rea, în afară de conștiința și rațiunea noastră naturală ${ }^{13}$. Totuşi, acestea ne permit să separăm justiția de injustiție şi să facem diferența între cei onești și cei mincinoși. Căci bunul simț ${ }^{14}$ a imprimat în mințile noastre principiile primordiale ale lucrurilor și ne-a dat o cunoștință generală a lor, prin care asociem Virtutea cu orice calitate onorabilă şi excelentă şi Viciul cu tot ce este detestabil şi condamnabil” ${ }^{15}$. Se poate observa că Cicero evită pentru moment să definească expres dreptul natural, dar îi dezvăluie implicit natura prin faptul că invocă instrumentele apte să îl perceapă, comune fiecărei ființe umane. Orice om se poate raporta la ideea de rațiune, conștiință și bun simț. Prin prisma experiențelor personale în care le-a utilizat ca instrumente de cunoaştere, omul poate ajunge să înțeleagă conținutul dreptului natural. Prin urmare, dreptul natural este mai mult decât o sumă de reguli obiective; el

\footnotetext{
${ }^{10}$ Idem, p. 25 , p. 30.

${ }^{11}$ Idem, p. 32.

${ }^{12}$ Idem, p. 33.

${ }^{13}$ Sublinierea ne aparține.

${ }^{14}$ Sublinierea ne aparține.

${ }^{15}$ Ibidem.
} 
este un mod de a percepe lucrurile şi începe cu facultatea rațională şi intuitivă de a discerne între bine şi rău. În acest sens, s-a afirmat că „,dreptul natural poate fi elaborat prin intermediul rațiunii naturale, în urma contemplării condiției umane. Rațiunea (...) nu este dreptul natural în sine, ci mijlocul prin care se descoperă justa aplicare a acestuia ${ }^{16 ”}$.

În continuare, Cicero definește dreptul natural astfel: „,(...) binele nu depinde de opinii: el este ceea ce este, prin chiar forța esenței sale. Dacă nu ar fi aşa, opiniile în sine ar da naștere binelui și fericirii, supoziție dintre cele mai absurde (...) $)^{17 ”}$. Astfel, simplul fapt că un criminal în serie ar considera că omorul este un lucru bun nu va schimba valoarea obiectivă a regulii de drept natural; opinia sa nu va transforma consecințele negative ale omorului în consecințe pozitive ${ }^{18}$. Cicero continuă afirmând că „,(..) dreptul nu a fost inventat de geniul oamenilor şi nu este nici un lucru descoperit în procesul de evoluție al societății; el este un principiu etern, care guvernează întreg universul, poruncind cu înțelepciune ceea ce este drept și interzicând ceea ce este greșit ${ }^{19}$ ”. În acelaşi sens, filosoful susţine că: ,adevărata lege este dreapta rațiune în acord cu Natura; este de aplicabilitate universală, neschimbătoare şi veșnică; ne cheamă la îndatoriri prin preceptele sale și ne îndepărtează de fapte rele prin interdicțiile sale. Ea nu își așează preceptele și interdicțiile

16 În același sens, A. Văllimărescu, Teoria dreptului natural în lumina istoriei și a doctrinelor filosofice, Ed. Al. T. Doicescu, București, 1930, p. 66. Autorul analizează teoria dreptului natural elaborată de Hugo Grotius potrivit căreia dreptul natural este o totalitate de principii universale și neschimbătoare care decurg din natura lucrurilor și din natura omenească, arătând că dreptul natural este degajat din natură de rațiunea omenească.

${ }^{17}$ M. T. Cicero, Treatise on the Laws [51 BC] (precit.), p. 34.

18 Considerăm importantă evidențierea obiectivității dreptului natural, mai ales în epoca marcată de relativism (juridic și filosofic) în care trăim.

${ }^{19}$ M. T. Cicero, Treatise on the Laws [51 BC] (precit.), p. 45.

\section{2}


asupra oamenilor buni în van, după cum niciunele nu au vreun efect asupra celor răi. Este un păcat a încerca să modifici această lege, nici nu este permis a încerca să abrogi vreo parte a ei și este imposibil să o distrugi în întregime. Nu putem fi eliberați de obligațiile ei de către Senat sau de către Oameni, și nu trebuie să căutăm în afara noastră lămurirea sau interpretarea ei” ${ }^{20}$.

Câtă valoare dobândesc afirmațiile lui Cicero despre dreptul natural în lumina evenimentelor din cel de-Al Doilea Război Mondial ${ }^{21}$ în cadrul cărora „dreptul degenerat”22 a produs consecințe dezastruoase asupra umanității. Doar acest conflict între cele două tipuri de drept și consecințele sale au putut demonstra cu adevărat justețea dreptului natural şi necesitatea reîntoarcerii spre acesta. S-a observat astfel că teorii ale dreptului natural au renăscut cu precădere în Republica Federală Germania după cel de-Al Doilea Război Mondial $^{23}$ şi că antitotalitarismul a contribuit la atenuarea pozitivismului juridic $^{24}$ și la nașterea doctrinei universalității drepturilor omului 25 . O teorie

${ }^{20}$ Cicero, De Republica, III, xxii, 33 apud A.P. D'Entrèves, Natural Law - An Introduction to Legal Philosophy (precit.), p. 20-21.

${ }^{21}$ Şi în lumina evenimentelor care au urmat în statele comuniste.

22 Expresie preluată din B. Rüthers, Dreptul degenerat. Teorii ale dreptului și juriști proeminenți în cel de-al Treilea Reich (tradusă de M. Balan), Ed. Universității „Alexandru Ioan Cuza”, Iași, 2005.

${ }^{23}$ A. Aarnio, On Legal Reasoning, Ed. Turun Yliopisto, Turku, 1977, p. 28.

24 În acest sens, în contextul unei discuții cu privire la pozitivismul juridic radical care caracterizează regimurile totalitare, s-a afirmat că persoanele care se află la putere nu acordă atenție dreptului natural pentru că acesta este de regulă invocat în defavoarea lor. Astfel, în timpul perioadei naziste, discuțiile legate de dreptul natural au fost suprimate. Această concepție - că nu există sursă a dreptului în afara voinței Führer-ului - este specifică formelor despotice de guvernământ. A se vedea J. Leclercq, Suggestions for Clarifying Natural Law, Natural Law Forum, Vol. 2, 1957, p. 66.

${ }^{25}$ R. Primus, A Brooding Omnipresence: Totalitarianism in Postwar Constitutional Thought, The Yale Law Journal, 1996, p. 427.

1013

SUBB Iurisprudentia nr. 4/2020 
a unor drepturi fundamentale universale şi obiective a creat cadrul pentru condamnarea acțiunilor unui stat, indiferent de conținutul dreptului său pozitiv $^{26}$. S-a ajuns astfel, după îndelungate convulsii istorice, înapoi la principiul elementar postulat de Cicero potrivit căruia unele acțiuni sunt pur şi simplu greşite, indiferent că sunt sau nu autorizate de dreptul pozitiv ${ }^{27}$.

Reconfirmarea valorii dreptului natural în urma experimentării consecințelor negative ale unui drept pozitiv nedrept ${ }^{28}$ a produs mai multe transformări pozitive în plan juridic după cel de-al doilea război mondial şi după căderea regimurilor comuniste. Astfel, în primul rând, existența unui conflict între dreptul natural și dreptul pozitiv a repus în discuție problema legitimităţii revoluției29 în sistemele democratice. Complexitatea acestei probleme a fost sesizată încă din perioada interbelică. În acest sens, Mircea Djuvara afirma următoarele: „Legea aşadar, trebuie să fie dreaptă. Pentru că trebuie să fie dreaptă, ea trebuie ascultată. Nu ne putem uşor face judecătorii ei, cât timp ea dăinuiește, căci am face o nedreptate și mai mare. Nu ar mai fi într-adevăr nici o măsură, căci fiecare ar ajunge să-şi facă singur dreptate. Dar, sunt și legi rele. Sunt unele chiar criminale, cum dovedește istoria și cum e uşor de văzut. În acest caz, oamenii cu simțul dreptății trebuie să lupte pentru schimbarea lor. Această luptă este o datorie sfântă, ca orice luptă pentu dreptate. Chiar dacă o lege rea nu ne atinge numaidecât, ci face rău numai

\footnotetext{
${ }^{26}$ Idem, p. 430.

${ }^{27}$ Idem, p. 431.

${ }^{28}$ Ne referim la dreptul nazist și la dreptul specific sistemelor comuniste. Expresia îi aparține filosofului Mircea Djuvara. În acest sens, a se vedea M. Djuvara, Eseuri de filosofie a dreptului, Ed. Trei, București, 1997, p. 181.

${ }^{29}$ Această problemă poate fi rezumată astfel: în ce măsură este legitimă nesupunerea faţă de norme de drept pozitiv vădit contrare dreptului natural?
}

\section{4}


altora, totuși ea se va răsfrânge și asupra noastră”30. Fără a intra în detalii cu privire la această problematică atât de complexă, subliniem totuși că dreptul natural constituie argumentul cel mai important pentru justificarea dreptului la revoluție ${ }^{11}$. Conflictul dintre dreptul natural şi dreptul pozitiv scade gradul respectării voluntare a normelor juridice datorită faptului că acestea din urmă obligă persoanele să acționeze împotriva propriei conștiințe $^{32}$, situație care conduce la creșterea importanței constrângerii statale 33 pentru asigurarea respectării normelor. Constrângerea statală, la rândul său, amplifică tensiunea acumulată între persoane şi stat, conducând, în cele din urmă, la autodistrugerea sistemului de drept pozitiv prin revoluție, având în vedere că statul nu va avea la nesfârşit resurse suficiente pentru a reduce la tăcere persoanele prin forța sa coercitivă ${ }^{34}$.

A doua consecință importantă a conflictului dintre dreptul natural și dreptul pozitiv specific evenimentelor din timpul și de după cel de-Al Doilea Război Mondial constă în renașterea doctrinei drepturilor fundamentale ale omului. Atacul sistematic la adresa acestora săvârşit de regimurile totalitare,

\footnotetext{
${ }^{30}$ M. Djuvara, Filosofia contemporană și dreptul, Ed. Grinta, Cluj-Napoca, 2005, p. 289.

31 În acest sens, a se vedea T. Ginsburg, D. Lansberg-Rodriguez, M. Versteeg, When to Overthrow your Government: The Right to Resist in the World's Constitutions, UCLA Law Review, No. 6o, 2013, p. 1221. În același sens, H.W.J. Palmer, A Definition of Law, American Bar Association Journal, 1936, p. 70.

${ }^{32}$ I. N. Lungulescu, Drept şi dreptate (precit.), p. 119. În acelaşi sens, a se vedea, E. Carbonara, F. Parisi, G. von Wangenheim, Unjust Laws and Illegal Norms, University of Minnesota Law School, Legal Studies Research Paper Series No. 08-03, p. 6, (https://papers.ssrn.com/sol3/papers.cfm?abstract id=1088742 - site accesat în data de 20.04.2020).

33 R.M. Goruneanu, Ideea de drept și procesul ei de formațiune, Tipografia Copuzeanu, București, 1931, p. 97-99.

${ }^{34}$ Revoluțiile împotriva regimurilor comuniste din statele est-europene constituie un exemplu în acest sens.
}

\section{5}


sub egida sistemelor lor juridice, a dat naștere unei reacții pe măsură dezvoltarea unei noi ramuri de drept internațional având ca scop protecția drepturilor omului. Până la atrocitățile comise de sistemele totalitare ale secolului trecut, respectarea drepturilor omului depindea exclusiv de consacrarea lor în sistemele de drept intern. Conflictul dintre dreptul natural şi dreptul pozitiv a evidențiat necesitatea garantării lor la nivel internațional. Această protecție internațională a drepturilor omului a fost ulterior receptată şi implementată la nivel național, mecanismele de drept constituțional jucând un rol esenţial în acest sens. Astfel, este binecunoscută, spre exemplu, implementarea jurisprudențială de către instanțele constituţionale europene a conceptelor și standardelor create de Curtea Europeană a Drepturilor Omului în domeniul protecției drepturilor fundamentale35. Integrarea garanțiilor create la nivel internațional în sistemele de drept intern a condus totodată la juridicizarea drepturilor fundamentale, depăşindu-se „faza politică” a renașterii lor, specifică dreptului internațional.

$\mathrm{Nu}$ în ultimul rând, conflictul dintre dreptul natural și dreptul pozitiv a conferit noi valențe principiului statului de drept $^{36}$, acesta devenind esențial pentru reformarea fostelor state totalitare ${ }^{37}$. Principiul în discuție semnifică faptul că şi statul, prin agenții săi, trebuie să se supună dreptului, chiar dacă poziția sa de superioritate față de particulari l-ar tenta să nu respecte această

\footnotetext{
${ }^{35}$ În acest sens, a se vedea B. M. Zupančič, Constitutional Law and the Jurisprudence of the European Court of Human Rights: An Attempt at a Synthesis, Journal for Constitutional Theory and Philosophy of Law, Vol. 1, 2003.

${ }^{36} \mathrm{Cu}$ privire la legătura dintre dreptul natural și statul de drept în context post-totalitar, a se vedea R.P. George, Reason, Freedom and the Rule of Law: Their Significance in the Natural Law Tradition, American Journal of Jurisprudence, Vol. 46, 2001.

37 În acest sens, a se vedea F. Emmert, Administrative and Court Reform in Central and Eastern Europe, European Law Journal, Vol. 9, No. 3, 2003.
}

1016 
obligație. Scopul principiului statului de drept este de a preveni arbitrariul statal. $\mathrm{Cu}$ toate acestea, efectivitatea principiului depinde în practică de semnificația acordată dreptului în acest context. Astfel, considerăm că dreptul trebuie să aibă un anumit conținut calitativ în sensul conformității sale cu dreptul natural pentru ca principiul statului de drept să îşi atingă scopul. Ce valoare ar mai avea acest principiu dacă s-ar admite că dreptul pozitiv poate conține norme vădit contrare dreptului natural? Respectarea de către stat a unui drept pozitiv nedrept nu ar putea contribui la prevenirea arbitrariului, ci dimpotrivă, l-ar prolifera ${ }^{3}$. Mai mult decât atât, chiar dacă dreptul pozitiv este conform dreptului natural, exigențele statului de drept impun ca normele juridice să fie respectate de stat atât în litera, cât și în spiritul lor. Abuzurile statelor se manifestă cel mai adesea prin încălcarea spiritului (scopului) normelor, cu respectarea literei lor. Statele recurg la astfel de abuzuri deoarece acestea sunt aproape imposibil de probat ${ }^{39}$, prezentând o aparență de legalitate. Spre exemplu, este binecunoscut faptul

\footnotetext{
38 În acest sens, a se vedea hotărârea Streletz, Kessler şi Krenz c. Germania pronunțată de Curtea Europeană a Drepturilor Omului în data de 22 martie 2001 (https://hudoc.echr.coe.int - site accesat în data de 28.10.2020). În contextul condamnării penale a trei foști funcţionari de stat ai Republicii Democrate Germane pentru instigare la omor în cazul persoanelor care doreau să treacă dincolo de zidul Berlinului, instanța constituțională germană a afirmat că cerințele unei justiții obiective împiedică un stat de drept să accepte cauze justificative derivând din legi sau practici contrare respectării drepturilor omului. Există prevederi legale care își pierd statutul de lege pentru că sunt în opoziție față de principii legale care sunt aplicabile indiferent că sunt sau nu recunoscute de Stat (§ 65). Curtea Europeană a preluat concluziile instanței constituționale germane, adăugând că instanțele unui stat de drept, care au luat locul celor din regimul trecut, nu pot fi criticate pentru aplicarea și interpretarea unor legi existente la momentul comiterii infracțiunii în lumina principiilor unui stat de drept (§ 81).

${ }^{39}$ Intențiile egoiste care motivează adoptarea unor norme juridice sunt adesea foarte dificil de probat prin elemente obiective.
}

1017

SUBB Iurisprudentia nr. 4/2020 
că în România ${ }^{40}$ practica modificării legilor electorale înainte de alegeri (și nu numai), vizează de regulă menținerea puterii de către cei aleși, și nu îmbunătățirea sistemului electoral. Această practică constituie un astfel de abuz de drept, având în vedere că litera legii este respectată (Constituția permite modificarea legilor electorale), dar scopul acesteia (îmbunătățirea sistemului electoral) este încălcat prin înlocuirea sa cu un scop egoist (menținerea puterii pentru obținerea de beneficii personale) ${ }^{41}$. Rolul primordial al principiului statului de drept este de a preveni tocmai abuzurile de acest tip, care au de-a face cu distorsionarea scopului ideal al legii, și nu cu nerespectarea legii în sens formal.

În concluzie, definiția contemporană a dreptului natural nu poate fi separată de protecția drepturilor fundamentale în fața arbitrariului statal. Această protecție poate fi asigurată doar în cadrul unui stat de drept. În măsura în care statul alunecă înspre totalitarism, dreptul la revoluție derivând din dreptul natural rămâne singura alternativă legitimă pentru garantarea protecției drepturilor fundamentale și restabilirea unui stat de drept.

\section{Argumente care demonstrează existența dreptului natural}

Argumentul suprem în favoarea recunoașterii existenței dreptului natural este existența ființei umane în sine. Aceasta prezintă anumite

\footnotetext{
${ }^{40} \mathrm{Cu}$ privire la respectarea principiului statului de drept în România, a se vedea P. Blokker, Romanian Constitutionalism: Form Without Content?, 2012, (https://papers.ssrn.com/sol3/papers.cfm?abstract $\mathrm{id}=2146568$ - site accesat în data de 20.04.2020).

41 Pentru o discuție cu privire la respectarea principiului statului de drept în contextul modificării legilor electorale, a se vedea Decizia Curții Constituționale nr. 471 din 14 noiembrie 2013 (publicată în M. Of. nr. 754 din 4 decembrie 2013).
}

\section{8}


caracteristici naturale (care îi conferă anumite drepturi înnăscute și inalienabile) și funcționează după anumite principii ${ }^{2}$. Dreptul natural decurge din ființa umană, iar o negare a dreptului natural ar fi echivalentă cu o negare a naturii umane. Astfel, existența dreptului natural (ca origine a dreptului pozitiv) este demonstrată de marele număr de asemănări și analogii ce se întâlnesc în sistemele juridice ale tuturor popoarelor, care confirmă identitatea fundamentală a naturii umane, în care dreptul îşi are rădăcinile sale43. În acelaşi sens, s-a afirmat că există dovezi implicite ale dreptului natural în toate acele norme juridice care reflectă atât de spontan preceptele conştiinței umane ${ }^{44}$ încât sunt caracteristice tuturor sistemelor juridice ale statelor civilizate 45 .

Consecința crucială a faptului că dreptul natural decurge din ființa umană și constituie standardul prin prisma căruia se măsoară dreptul pozitiv ${ }^{46}$ este că persoana umană reprezintă reperul în raport de care trebuie analizată legitimitatea dreptului existent. Dreptul există pentru persoane şi nu vice versa. De aceea, orice analiză a legitimității dreptului care face

\footnotetext{
42 Detalii cu privire la conținutul acestor principii vom oferi în secțiunea următoare dedicată conținutului dreptului natural. Pentru a oferi totuși un exemplu, este binecunoscut faptul că raporturile juridice civile sunt ghidate de principiul bunei-credințe prezumate. În același sens, în activitatea de legiferare, legiuitorul nu pleacă de la prezumția că nimeni nu va respecta legea, ci consideră că majoritatea destinatarilor normelor juridice le vor respecta de bunăvoie. De aceea, există numeroase norme juridice fără sancțiune. Principiul bunei-credințe prezumate își are originea în principiul natural al încrederii care guvernează relațiile dintre oameni.

${ }^{43}$ G. del Vecchio, Lecții de filosofie juridică, Ed. Europa Nova, București, 1999, p. 29, p. 181.

${ }^{44}$ Cum ar fi interdicția omorului, violului, furtului etc.

${ }^{45}$ H. R. McKinnon, Natural Law and Positive Law, Notre Dame Lawyer, No. 2, Vol. XXIII, 1948, p. 127-128.

${ }^{46}$ G. del Vecchio, Lecții de filosofie juridică (precit.), p. 181, p. 347.
}

\section{9}


abstracție de binele omului este absurdă 47 . În acest sens, s-a susținut că „persoana umană este legitimul legitimant în raport cu care etica și dreptul sunt legitimul legitimat. Odată cu persoana, regresia infinită a legitimării este blocată, deoarece cea care chestionează, suspectează orice legitimitate este tocmai o persoană. (...) Ca atare, dacă tocmai persoana (și nimic altceva) este singura abilitată să interogheze radical legitimitatea oricărei structuri, persoana este deja legitimul (...). Pentru că este singura care poate destitui o legitimitate, este singura care poate acorda legitimitate. Și asta doar pentru că ea este deja legitimă (...). Numai ea este de aşa natură încât nu putem să o considerăm obiect, deoarece este subiect (...)”48.

Pentru evaluarea legitimității dreptului pozitiv, ființa umană recurge la facultatea sa internă de a distinge între justiție și injustiție49. Această capacitate specifică ființei umane a fost sesizată și de filosoful Mircea Djuvara $^{50}$. Astfel, acesta observa următoarele: ,pot exista date juridice și fără

47 Aceste afirmații nu trebuie înțelese ca făcând apologia nerespectării dreptului pozitiv, în orice condiții, în măsura în care acesta contravine dreptului natural, ci ca încurajând critica dreptului pozitiv din acest punct de vedere. În acest sens, s-a afirmat că ,a face în studiul dreptului pozitiv completă abstracțiune de această gândire independentă, care determină ceea ce e drept și nedrept, ar fi o gravă eroare pentru știința juridică”. A se vedea M. Djuvara, Drept rațional, izvoare și drept pozitiv, Ed. Librăriei Socec \& Co. S.A., București, 1934, p. 8.

${ }^{48}$ V. Mureşan, Relativismul juridic, teză, Cluj-Napoca, 2008, p. 106.

${ }^{49}$ G. del Vecchio, Lecții de filosofie juridică (precit.), p. 319. Potrivit autorului citat, ,,(...) avem o facultate originară, ce nu poate fi dedusă din experiență, de a deosebi justiția de injustiție. Chiar Aristotel scotea în relief această facultate sau sentiment al justului și injustului, considerându-l ca pe un caracter fundamental și specific al omului față de celelalte specii animale".

${ }^{50}$ Precizăm cu această ocazie că Mircea Djuvara credea în existenţa unui drept care depăşeşte cadrul dreptului pozitiv, pe care îl numea drept rațional. A se vedea M. Djuvara, Drept și drept pozitiv, Extras din revista „Analele Facultății de Drept”, București, 1940, p. 6 - „Cred a putea afirma că există drept și în afară de dreptul pozitiv și că întreg dreptul nu se reduce numai la normele puse în mod expres de dreptul pozitiv". Autorul a ales denumirea de drept rațional 
nici o referire la vreo normă de drept pozitiv, pentru că putem emite judecăţi de drept chiar făcând cu desăvârșire abstracție de dispozițiile pozitive; putem anume judeca faptele sociale numai prin rațiune, din punct de vedere al justiției pure. Așa judecăm de obicei faptele oamenilor și abia în urmă căutăm a vedea dacă ele sunt în acord și cu regulile dreptului pozitiv ${ }^{51}$. De câte ori, de exemplu, se întâmplă să constatăm o faptă reprobabilă, noi simțim mai întâi injustiția ei, condamnând-o cu judecata noastră, şi numai după aceea cercetăm dacă și cum e prevăzută în texte, în codul penal, în codul civil sau în vreo altă lege. Putem judeca prin aprecieri libere de justiţie chiar şi regulile dreptului pozitiv; putem constata un drept pozitiv nedrept. Chiar și înăuntrul cadrelor dreptului pozitiv, juristul emite de multe ori asemenea aprecieri de justiție; părțile, apărătorii și avocații le invocă fără încetare; judecătorii încep şi ei prin a constata dacă reclamațiile justițiabililor sunt drepte sau nedrepte și nu cercetează decât în urmă modul cum trebuie să li se aplice dispozițiile legale. În orice caz, teoreticienii dreptului sunt obligați adeseori să procedeze în acest fel" ${ }^{2}$.

Considerăm, în același sens, că această evaluare a dreptului pozitiv, realizată fără încetare de toți actorii lumii juridice, este o realitate de necontestat și demonstrează preexistența unui reper utilizat în acest proces - dreptul natural. $\mathrm{Cu}$ toate acestea, judecata dreptului pozitiv în lumina dreptului natural este atât de firească încât trece adesea neobservată, fiind tot atât de des negată de cei care o practică. Într-o epocă marcată de pozitivism

pentru ,,a învedera astfel că nu suntem în fața unor simple aserțiuni sentimentale sau a unor pure impulsuri oarbe, care nu ar avea nimic de a face cu rațiunea şi logica”. A se vedea M. Djuvara, Eseuri de filosofie a dreptului (precit.), p. 182.

${ }^{51}$ Sublinierea ne aparține.

${ }^{52}$ M. Djuvara, Eseuri de filosofie a dreptului (precit.), p. 181.

\section{1}


juridic, actorii lumii juridice au ajuns să nu mai fie conștienți că se raportează fără încetare la preceptele dreptului natural.

Aceeași idee este ilustrată de Mircea Djuvara prin raportare la activitatea de interpretare judiciară: „Pe de altă parte, nu am nevoie, cred, să vă spun aci, că, dacă uneori judecătorii aplică strict legea, în alte cazuri ei îi dau o interpretare extensivă şi chiar câteodată o depăşesc până a ajunge în contrazicere cu formulele ei. În toate aceste cazuri, cu voie sau fără voie, judecătorii judecă legea însăși; dacă o aplică întocmai ei apreciază implicit în mod logic că, în cazul judecat, legea trebuie respectată aşa cum e; dacă o extind sau dau chiar o soluție contrarie ei, acest fapt implică neapărat judecata logică că dispoziția respectivă a legii nu trebuie aplicată întocmai. Această operațiune rațională de apreciere a legii de la caz la caz se face, în mod evident, şi într-o ipoteză şi în alta, pe baza unor principii superioare legii însăşi, principii care sunt juridice și care sunt liber gândite, deși actul logic pe care îl implică nu e decât rar explicitat: ea este la fundamentul întregului drept pozitiv. Se observă astfel cum, din acest punct de vedere, dreptul pozitiv, în întregimea lui, e dominat de un alt drept care-i este superior şi care nu e altceva decât un drept liber gândit, adică un drept rațional”"53. Prin cele expuse anterior, autorul arată astfel că supraexistența dreptului natural este demonstrată de faptul că judecătorul judecă legea în mod instinctiv, în cadrul operațiunii de interpretare judiciară54.

În acelaşi timp, existența dreptului natural poate fi dovedită pe baza raționamentului per a contrario. Din acest punct de vedere, Mircea Djuvara

\footnotetext{
${ }^{53}$ M. Djuvara, Drept şi drept pozitiv (precit.), p. 10-11.

${ }^{54}$ Reiterăm că scopul acestei secțiuni este de a demonstra existența dreptului natural, şi nu de a determina limitele constituționale în care judecătorul poate adapta în mod legitim dispozițiile dreptului pozitiv în funcție de preceptele dreptului natural.
}

1022 
a ajuns la concluzii similare cu cele susținute de Cicero: ,,a confunda dreptul cu dreptul pozitiv și a nu recunoaște nimic juridic în afară de acesta din urmă este deci pur şi simplu a reduce dreptul la forță. (...) Nicio problemă juridică nu s-ar mai putea deci pune în realitate; nu ar exista decât probleme practice de oportunitate individuală, pentru a ști cum are fiecare interes a se conforma sau nu şi prin ce mijloace s-ar putea supune sau sustrage ordinului dat de o persoană, care dispune de cea mai mare putere materială într-o organizație socială dată. Simțul comun, de care trebuie să ținem ori cum seamă, s-ar revolta de asemenea, căci avem conştiința limpede, că dreptul nu este forța, că dreptul trebuie respectat pentru sine, că forța trebuie să se pună în serviciul său şi că reprezintă el însuși o forță, poate cea mai mare (...)”物. Autorul încheie prin a afirma că ,„intre normele stabilite prin gândirea noastră independentă asupra justiției acțiunilor omenești și normele dreptului pozitiv există aşa dar, cu siguranță, o relațiune, chiar dacă nu există identitate. Această relațiune trebuie descoperită și analizată” 56 .

Totodată, faptul că dreptul pozitiv arată într-un anumit fel, şi nu în altul, demonstrează că acesta oglindește un drept superior ${ }^{57}$. Dacă nu ar exista un drept natural decurgând din natura umană, dreptul pozitiv ar fi o pură

55 M. Djuvara, Drept raţional, izvoare şi drept pozitiv (precit.), p. 9. În acelaşi sens, A. Văllimărescu, Teoria dreptului natural în lumina istoriei și a doctrinelor filosofice (precit.), p. 14 - ,,sau există o regulă din afară care se impune și legiuitorului; sau dreptul este lăsat prada evenimentelor și a circumstanțelor, citiți a forței guvernanților”.

${ }^{56}$ M. Djuvara, Drept rațional, izvoare și drept pozitiv (precit.), p. 9.

${ }^{57}$ A se vedea V. Mureșan, Relativismul juridic (precit.), p. 15. „Faptul că dreptul arată astfel (și este greu de conceput un drept în care persoana, demnitatea, libertatea sau proprietatea să fie interzise!) este pentru noi un argument că, deși el a arătat altfel și poate să devină altfel (la nivel pozitiv), el nu are voie să își schimbe aceste valori. Chiar și dreptul pozitiv al statelor totalitare păstra măcar retorica acestor valori, chiar dacă în practică sau prin interdicții camuflate, el era, dacă se poate spune așa, un drept nedrept...”

\section{3}


întâmplare, fiind dictat de voința unor legiuitori ale căror reglementări nu ar putea fi anticipate pe baza vreunui principiu. Cu toate acestea, în majoritatea sistemelor juridice, dreptul pozitiv are o arhitectură de bază similară, compusă din principii fundamentale de drept ${ }^{5}$, fiind, de regulă, conform cu dreptul natural59, chiar dacă cele două sfere nu se suprapun în totalitate.

\section{Conținutul dreptului natural}

\section{A. Legătura dintre dreptul natural și drepturile fundamentale ale omului}

În prezența secțiune, vom clarifica conținutul dreptului natural, nu însă înainte de a evidenţia obiectul acestuia.

Funcția principală a dreptului natural este de a proteja anumite valori intrinseci ființei umane, traduse prin noțiunea de drepturi fundamentale ale omului. Din natura umană (și nu din dreptul pozitiv) decurg atât drepturile fundamentale, cât și principiul elementar de drept natural care impune necesitatea protecției acestora. Orice tentativă de determinare a conținutului concret al dreptului natural trebuie să pornească de la următoarea premisă fundamentală: omul este înzestrat din naștere cu o sumă de drepturi

\footnotetext{
58 În sistemele juridice laice, care sunt majoritare la nivel global, se regăsesc în mare parte aceleași principii fundamentale de drept, chiar dacă poartă uneori denumiri diferite, acestea fiind reglementate de regulă la nivel constituțional.

59 Sunt excepționale sistemele juridice în care dreptul pozitiv contravine în mare parte dreptului natural, cum ar fi cele specifice regimurilor politice dictatoriale. Chiar și în acele cazuri, contradicția dintre cele două tipuri de drept se întâlnește cu precădere la nivelul practicilor, și nu la nivel legislativ, având în vedere că regimurile dictatoriale păstrează în aparență un drept pozitiv conform dreptului natural.
}

1024 
naturale, care trebuie protejate prin intermediul dreptului. Această protecție nu trebuie justificată în niciun fel; ea se impune automat pentru că drepturile în discuție au valoare prin însuși faptul că sunt derivate din caracteristici naturale ale omului ${ }^{60}$.

Existența drepturilor fundamentale nu depinde de recunoaşterea acestora de către stat prin intermediul dreptului pozitiv. Ele există indiferent că sunt sau nu consacrate ori protejate din punct de vedere juridic ${ }^{61}$. Această trăsătură a drepturilor fundamentale consolidează strânsa legătură dintre acestea și dreptul natural ${ }^{62}$. Conexiunea în discuție a fost amplu analizată în doctrină ${ }^{63}, \quad$ accentuându-se importanța recunoașterii independenței drepturilor fundamentale față de sistemele de drept pozitiv. În acest sens, s-a afirmat că „remarcabila permanență a dreptului natural demonstrează vitalitatea teoriilor care încearcă să lege drepturile omului de principii

60 De exemplu, omul este o ființă liberă (funcționează în condiții optime dacă este liber), caracteristică din care decurge dreptul său la libertate (fizică, de gândire etc.).

${ }^{61}$ În acest sens, s-a afirmat că ,,viața, libertatea și proprietatea nu există pentru că omul a creat legi. Dimpotrivă, faptul că viața, libertatea și proprietatea au preexistat l-a determinat pe om să creeze legi (...)". A se vedea F. Bastiat, The Law, The Foundation for Economic Education Publishing House, Irvington-on-Hudson, New York, 1990, p. 6.

${ }^{62}$ Potrivit școlii dreptului natural, dezvoltată de Grotius și discipolii acestuia, dreptul natural își are baza în drepturile imprescriptibile ale omului. Dreptul natural presupune existența unor drepturi,care aparțin în mod originar și esențial omului, care sunt inerente naturii sale și de care acesta se bucură tocmai pentru că este om, independent de vreun act anume din partea sa”. În acest sens, a se vedea A. Văllimărescu, Teoria dreptului natural în lumina istoriei și a doctrinelor filosofice (precit.), p. 66 și J.J. Burlamaqui, Principes du droit naturel, 1747, capitolul VII, § 8 apud Fr. Sudre, Drept european și internațional al drepturilor omului, Ed. Polirom, 2006, București, p. 45. De asemenea, cu privire la legătura dintre școala dreptului natural și adoptarea în cursul Revoluției Franceze a Declarației drepturilor omului şi ale cetățeanului, a se vedea M. Djuvara, Teoria generală a dreptului, Vol. I, Ed. Librăriei Socec \& Co., București, 1930, p. 140.

${ }^{63}$ A se vedea, spre exemplu, I. M. Zlătescu, Drepturile omului - un sistem în evoluție, Ed. Institutul Român pentru drepturile omului, București, 2008, p. 27.

\section{5}


superioare. (....) ar fi periculos ca drepturile omului să se întemeieze doar pe autoritatea statală, deoarece aceasta ar putea fi o poartă deschisă arbitrarului şi totalitarismului. Drepturile omului relevă concepția dreptului natural după care omul, pentru că este om, posedă un ansamblu de drepturi inerente naturii sale"64. În același sens, legătura dintre dreptul natural și drepturile omului este demonstrată de anterioritatea acestora din urmă faţă de normele juridice care le consacră. Astfel, atât textele juridice naționale, cât și cele internaționale apar ca „recunoașteri” sau „declarații” de drepturi. Recunoașterea „dreptului de a fi om” este o valoare anterioară oricărui act politic, textele internaționale (sau naționale) doar transformând drepturile omului în categorii juridice prin garantarea unui regim de protecție al acestora $^{65}$.

\section{B. Protecția drepturilor individuale - principiu fundamental de drept natural}

După cum vom detalia în secţiunile următoare, dreptul natural este în principal compus dintr-o sumă de principii cu un grad foarte ridicat de generalitate. Datorită faptului că sunt atât de generale, unele dintre principiile în discuție nu sunt consacrate expres prin norme juridice; totuşi, ele impregnează întreaga textură a dreptului pozitiv.

În această secțiune, vom sublinia importanța principiului ultim al dreptului natural: principiul protecției drepturilor individuale. Acest

\footnotetext{
${ }^{64} \mathrm{~J}$. Renucci, Tratat de drept european al drepturilor omului, Ed. Hamangiu, București, 2009, p. 2-3.

${ }^{65}$ Fr. Sudre, Drept european și internațional al drepturilor omului, Ed. Polirom, 2006, București, p. 46.
}

1026 
principiu inspiră activitatea de legiferare și ghidează interpretarea normelor juridice. Din el se nasc norme de drept pozitiv, care au scopul de a contribui, direct sau indirect, la materializarea sa. În acest sens, Ayn Rand afirma următoarele: „,indiferent dacă se consideră că omul este un produs al unui Creator sau al naturii, problema originii omului nu schimbă faptul că el este o entitate de un fel deosebit, și anume o ființă rațională, că nu poate funcționa sub constrângere şi că drepturile constituie condiția necesară pentru succesul modului său specific de supraviețuire. ${ }^{66}$ ” Potrivit aceleiași autoare, „dacă e ca oamenii să conviețuiască într-o societate paşnică, productivă, rațională, şi să aibă de-a face unii cu alţii întru avantajul lor reciproc, ei trebuie să accepte principiul social fundamental fără de care nu este posibilă nicio societate morală sau civilizată, și anume principiul drepturilor individuale ${ }^{67}$. A recunoaşte drepturile individuale înseamnă a recunoaște şi accepta condițiile necesare naturii umane pentru propria-i supraviețuire"68.

Subliniem, în același sens, că legitimitatea oricărui sistem de drept pozitiv depinde de recunoaşterea și respectarea acestui principiu. Deturnarea dreptului pozitiv înspre urmărirea altor scopuri, în afara protecției drepturilor individuale, a sfârșit în istorie prin a avea consecințe tragice. Recunoașterea preeminenței acestui principiu nu înseamnă negarea caracterului social al dreptului şi a limitelor inerente exercitării drepturilor individuale în societate. Totuși, înainte de societate, a existat ființa umană, în individualitatea sa. Ea

\footnotetext{
${ }^{66}$ Medalion Ayn Rand, A. Leibovici (traducere), Krisis nr. 3/1996, p. 21. Sublinierile ne aparţin. ${ }^{67}$ Sublinierea ne aparține.

${ }^{68}$ Medalion Ayn Rand (precit.), p. 25.
}

1027 
are consistență, spre deosebire de stat sau societate, care rămân adesea concepte abstracte în spatele cărora se ascund interese ilegitime ${ }^{69}$.

\section{Particularizarea treptată a principiului protecției drepturilor individuale}

În această secțiune, vom prezenta modalitatea în care este particularizat principiul ultim al protecției drepturilor individuale, recurgând la un exemplu preluat din doctrina americană ${ }^{70}$.

Harold R. McKinnon arăta că există trei nivele ale dreptului. Pentru a le diferenția, acesta a utilizat termenii de: principii, precepte și reguli ${ }^{71}$. Potrivit autorului, unul din principiile esențiale din care decurg celelalte forme de drept este alegerea binelui și evitarea răului ${ }^{2}$. Având în vedere cele prezentate în secțiunea anterioară, vom considera că principiul protecției drepturilor individuale este echivalent, la nivel conceptual, cu principiul

\footnotetext{
${ }^{69}$ Una dintre practicile specifice regimurile totalitare este tocmai manipularea conceptului de stat, ca entitate abstractă, în scopul promovării unor interese ilegitime de grup. Despre supradimensionarea statului în dauna drepturilor individuale în regimurile comuniste, a se vedea K. W. Colegrove, H. Bartlett, E. M. Hunt, Democracy versus Communism, D. Van Nostrand Company, Princeton, New Jersey, 1957, p. 42-43.

${ }^{70}$ H.R. McKinnon, Natural Law and Positive Law (precit.), p. 133-134. Menționăm că același proces al particularizării este aplicabil și în cazul principiilor de drept natural pe care le vom prezenta în următoarea secțiune.

${ }^{71}$ M. J. Adler, A Question About Law în Essays in Thomism, Sheed \& Ward, New York, 1942, p. 207, 212 apud H. R. McKinnon, Natural Law and Positive Law (precit.), p. 133-134. Sublinierile îi aparțin autorului.

72 În același sens, R.L. Hunt, Natural Law v. Positive Law: Interpreting Morality (precit.), p. 251-252. Deși suntem de acord că acest principiu de drept natural este unul fundamental, considerăm ca fiind principii preeminente acestuia ideea de persoană, respectiv principiul voinței libere. În acest sens, a se vedea secțiunea V.4.4.
}

1028 
alegerii binelui și evitării răului³. În continuare, autorul evidenția că acest principiu nu are valoarea unei concluzii deduse din premise, ci este o judecată intuitivă, apriorică sau primordială. De aceea, ea nu poate și nu trebuie să fie demonstrată.

Următorul nivel al dreptului, reprezentat de precepte, este compus din concluzii deduse în mod imediat și necesar din principii, acestea constituind mijloacele pentru atingerea binelui social exprimat prin intermediul principiilor74. Preceptele sunt uneori denumite principii secundare ale dreptului natural75. Atât principiile, cât și preceptele sunt inapte, prin ele însele, să reglementeze fapte, dar din motive diferite: principiile specifică doar scopul urmărit, iar reglementările necesită specificarea mijloacelor; preceptele specifică mijloacele, dar numai la modul general și fără a face referire la circumstanțe specifice, care sunt întotdeauna implicate în domeniul faptelor ${ }^{76}$. Pentru a ilustra această idee, autorul a utilizat exemplul preceptului care interzice uciderea. Bineînțeles că preceptul se referă la uciderea ilicită, dar acesta nu reușește să definească circumstanțele care fac ca uciderea să fie ilicită, spre deosebire de circumstanțele care ar putea să o justifice, omiţând totodată să determine pedeapsa pentru această faptă. Preceptul necesită particularizarea sa într-un şablon mai specific pentru a fi apt să reglementeze fapte concrete. Acest proces seamănă cu procesul prin care un meșter, pornind de la schema generală a unei case, ajunge să-i confere o formă specifică. Ambele etape sunt la fel de necesare pentru finalizarea

\footnotetext{
73 Protecția drepturilor individuale are semnificația binelui, iar distrugerea acestora are semnificația răului.

${ }^{74}$ H. R. McKinnon, Natural Law and Positive Law (precit.), p. 134-135.

${ }^{75}$ Ibidem.

${ }^{76}$ Ibidem.
}

1029 
casei. Tot așa, din procesul particularizării preceptelor iau naștere regulile pozitive - al treilea nivel al dreptului - doar acestea având aptitudinea de a reglementa stări de fapt specifice ${ }^{77}$. Se poate astfel observa că în acest caz, principiul protecţiei drepturilor individuale este particularizat până se ajunge la crearea unei norme penale complete care incriminează omorul, având ca scop protecția dreptului la viață.

Având în vedere cele expuse mai sus, concluzionăm această secțiune prin a afirma că dreptul pozitiv nu poate fi separat de dreptul natural. Primul derivă din al doilea în urma unui proces de particularizare.

\section{Alte principii de drept natural}

Pe lângă principiul protecției drepturilor individuale, care se concretizează în norme specifice de drept pozitiv, mai există și alte principii de drept natural, care decurg din modul firesc în care funcționează ființele umane, atât în individualitatea lor, cât și în raporturile cu ceilalți.

Aceste principii sunt, de regulă, mai generale decât principiile fundamentale de drept. La fel cum tulpinile unei plante se trag din rădăcini, principiile fundamentale de drept sunt concretizări sau prelungiri ale principiilor de drept natural, care se află la originea acestora. De aceea, o delimitare netă între cele două categorii de principii în raport de conţinutul acestora este dificil de realizat; principiile fundamentale de drept sunt adesea doar particularizări sau nuanțări ale principiilor de drept natural.

Înainte de a le prezenta succint, reiterăm că aceste principii „nu sunt rezultatul unei loterii istorice, ci rezultatul unei reflexii aprofundate asupra

\footnotetext{
${ }^{77}$ Ibidem.
} 
naturii umane"78; ele derivă din modul în care natura umană funcționează în condiții optime. În acest sens, s-a afirmat că „,filosofia dreptului sau dreptul natural este știința care expune primele principii ale dreptului, concepute de rațiune şi întemeiate pe natura omului, considerată în ea însăşi şi în raporturile sale cu ordinea universală a lucrurilor. (...) Filosofia dreptului învață și pregătește recunoaşterea pozitivă a idealului juridic (...)”79.

În acelaşi sens, considerăm că întoarcerea înspre originile dreptului pentru a identifica cele mai generale postulate ale sale este esențială, având în vedere că acestea reprezintă principala sursă de inspirație şi fundamentul legitim al dreptului pozitiv. Ele determină punctul de pornire în opera de legiferare, trasând totodată granițele legitimității acesteia. Tot ele constituie repere în opera de interpretare în cadrul căreia se parcurge drumul invers ${ }^{80}$ : de la norma concretă de drept pozitiv la principiile generale de drept natural care i-au dat naştere.

Astfel, subliniem că primul principiu de drept natural, care stă la baza eşafodajului dreptului pozitiv, este ideea de persoană ${ }^{81}$. Această idee fundamentează noțiunea de subiect de drept, operantă în toate ramurile dreptului. Valoarea persoanei, în calitatea sa de subiect de drept, nu poate fi pusă sub semnul întrebării. Această idee constituie un principiu ultim şi nedemonstrabil, care deşi prea general pentru a fi recunoscut ca atare prin intermediul normelor de drept pozitiv, se deduce implicit din numeroase

\footnotetext{
${ }^{78}$ V. Mureşan, Relativismul juridic (precit.), p. 312.

${ }^{79}$ G. del Vecchio, Lecții de filosofie juridică (precit.), p. 30.

${ }^{80}$ Tr. Pop, Drept procesual penal. Partea introductivă, Vol. I, Ed. Universul Juridic, p. 160. „Legiuitorul și interpretul parcurg același drum: numai cât îl parcurg în sens invers.”

${ }^{81}$ G. del Vecchio, Lecții de filosofie juridică (precit.), p. 348-349.
} 
prevederi legale ${ }^{82}$. În același timp, normele juridice se adresează exclusiv persoanelor, în individualitatea lor ${ }^{83}$, şi nu altor categorii de ființe sau obiecte.

Al doilea principiu de drept natural este principiul libertăţii de voință, care pleacă de la premisa că persoana beneficiază de o libertate înnăscută de a decide. Acest principiu are, de asemenea, un caracter ultim și nedemonstrabil (valoarea libertăţii nu poate fi argumentată) şi este prea general pentru a fi consacrat expres prin norme de drept pozitiv. Din acest principiu se nasc principii-consecință, acestea având valoarea unor principii fundamentale de drept. Astfel, ca principii-consecință generale, reținem următoarele: a) dreptul fundamental la libertate este inalienabil ${ }^{84}$; b) libertatea fiecăruia este limitată de libertatea altuia ${ }^{85}$; c) tot ce nu este interzis este permis, iar limitarea libertăților se interpretează restrictiv; d) principiul responsabilității ${ }^{86}$. Ca principii-consecință de ramură, reprezentând concretizări ale principiului libertății de voință, reținem, cu titlu de exemplu, principiul libertății contractuale ${ }^{87}$ și al consensualismului ${ }^{88}$, care consacră eficiența juridică a unirii voințelor libere.

\footnotetext{
${ }^{82}$ A se vedea, spre exemplu, art. 28 din Codul civil, care reglementează capacitatea civilă, recunoscută tuturor persoanelor. De asemenea, Codul penal operează cu noțiunea de persoană, ca subiect al răspunderii penale. A se vedea, în acest sens art. 1 alin. (2) din Codul penal: „nicio persoană nu poate fi sancționată penal (...)”. Sublinierea ne aparține.

${ }^{83}$ Bineînțeles că în această categorie intră și persoanele juridice. Totuși, subliniem că la baza noțiunii de subiect de drept stă persoana naturală; persoana juridică este doar o construcție legală fictivă care o imită.

${ }^{84}$ G. del Vecchio, Lecții de filosofie juridică (precit.), p. 348-349.

${ }^{85}$ Ibidem.

${ }^{86} \mathrm{Nu}$ pretindem că această enumerare are caracter exhaustiv.

${ }^{87}$ Pentru detalii, a se vedea I. Reghini, Ș. Diaconescu, P. Vasilescu, Introducere în dreptul civil, Ed. a 2-a, Ed. Sfera Juridică, Cluj-Napoca, 2008, p. 418.

${ }^{88}$ Ibidem, p. 481.
} 
Al treilea principiu elementar de drept natural, care urmează logic principiul libertății de voință, este principiul alegerii binelui şi evitării răului. Fără a dezvolta această problematică atât de complexă, întrucât depăşește tematica prezentei lucrări, menționăm că trasarea unei distincții între bine și rău fundamentează întreaga paradigmă juridică, care se bazează pe distincţia permis/interzis, respectiv legal/ilegal. Acest principiu îl antrenează pe următorul: alegerea răului atrage sancțiunea ca reacție a dreptului față de faptele prejudiciabile. În condițiile în care fiecare persoană este responsabilă de propriile fapte - responsabilitate care decurge din libertatea sa de a alege între bine şi rău - este natural ca alegerea binelui să atragă consecințe pozitive (evitarea sancțiunii), iar alegerea răului să atragă consecințe negative (aplicarea sancțiunii).

Analizând conținutul dreptului pozitiv, se poate observa că principiul responsabilității pentru propriile fapte care antrenează sancțiunea este un principiu general aplicabil în orice ramură de drept cu circumstanțierile de rigoare. În dreptul civil, principiul în discuție se manifestă prin principiile răspunderii civile delictuale și contractuale. Angajarea răspunderii civile atrage obligația de a repara prejudiciile produse altora, obligația în discuție constituind o formă de sancțiune ${ }^{89}$. Pe de altă parte, în dreptul penal, angajarea responsabilității atrage incidența sancțiunii penale ${ }^{90}$.

\footnotetext{
89 Potrivit teoriei lui Hugo Grotius, repararea pagubelor pricinuite altuia (damni culpa reparatio) constituie un principiu de drept natural. A se vedea E. Speranția, Introducere în filosofia dreptului, Tipografia „Cartea Românească”, Cluj, 1946, p. 97.

${ }^{90}$ Ibidem. În acest sens, Hugo Grotius consideră că meritarea pedepsei echitabile a celor care încalcă dreptul (poena inter homines meritum) constituie un principiu de drept natural.
}

\section{3}


Un alt principiu de drept natural care reprezintă o condiție sine qua non pentru dezvoltarea relațiilor interumane este încrederea. Aceasta din urmă exclude presupunerile negative cu privire la intențiile celeilalte persoane. În absența deciziei de a avea încredere (chiar dacă decizia în sine nu garantează că persoana respectivă este demnă de încredere), relațiile sunt sortite eșecului datorită temerii și incertitudinii cauzate de suspiciuni interminabile. $\mathrm{Cu}$ toate acestea, principiul încrederii nu are valoarea unui postulat despre onestitatea naturii umane. Principiul încrederii constituie mai degrabă o prezumție relativă care poate fi tradusă astfel: până la proba contrarie, orice persoană este prezumată ca fiind demnă de încredere. Acest principiu de drept natural decurge din respectul datorat ființei umane și din necesitatea de a garanta un fundament stabil relațiilor interumane.

Principiul de drept natural analizat se reflectă în dreptul pozitiv prin intermediul unor principii fundamentale de drept. Astfel, în dreptul civil, principiul încrederii se manifestă prin intermediul principiului neprezumabilităţii răului ${ }^{11}$. Conform acestui principiu, buna-credință se prezumă până la proba contrară. Dacă prezumția este răsturnată și se dovedește reaua-credință, aceasta din urmă se sancționează. În dreptul penal, principiul încrederii se manifestă prin intermediul prezumției de nevinovăție și a principiului in dubio pro reo ${ }^{92}$.

Un alt principiu de drept natural, care constituie un fundament pentru opera de legiferare și un reper în activitatea de interpretare judiciară este

\footnotetext{
${ }^{91}$ E. Speranția, Introducere în filosofia dreptului (precit.), p. 463. ${ }^{92}$ Ibidem.
} 
principiul echitățiiị. Având în vedere semnificațiile complexe ale acestui concept şi aplicabilitatea sa extinsă în sistemul juridic, ne vom referi în treacăt la un singur aspect al echităţii ce ține de raporturile dintre stat și particulari, și anume la egalitatea în fața legii și a autorităților publice94. Astfel, în contextul amintit, considerăm că existența privilegiilor și a discriminărilor 95 constituie una din ipotezele clasice de violare a echităţii ca principiu de drept natural. Încă din perioada Antichității ${ }^{96}$, a fost amintită regula potrivit căreia legile nu trebuie adoptate în favoarea unor indivizi determinați97. Cu toate acestea, nu trebuie uitat că interdicția privilegiilor și a discriminărilor nu se reduce la ipoteza legiferării, ci este aplicabilă în toate raporturile juridice dintre particulari și autoritățile publice.

În concluzie, menționăm că prezentarea principiilor de drept natural din cuprinsul acestei secțiuni nu are sub nicio formă caracter exhaustiv ${ }^{9} . \mathrm{Cu}$

${ }^{93} \mathrm{Cu}$ privire la legătura dintre echitate și dreptul natural a se vedea R.A. Newman, Equity in Comparative Law, International and Comparative Law Quarterly, Vol. 17, Issue 4, 1968.

94 În acest sens, s-a afirmat că principiul egalității decurge din calitatea de subiect de drept a fiecărui om. A se vedea G. del Vecchio, Lecții de filosofie juridică (precit.), p. 348-349.

95 În opinia Curții Constituționale, discriminarea se bazează pe noțiunea de excludere nejustificată de la un drept (Decizia Curții Constituționale nr. 62 din 21 octombrie 1993, publicată în M. Of. nr. 49 din 25 februarie 1994), în timp ce privilegiul se definește ca un avantaj sau favoare nejustificată acordată unei persoane/categorii de persoane (Decizia Curții Constituționale nr. 755 din 16 decembrie 2014, publicată în M. Of. nr. 101 din 09.02.2015). A se vedea T. Toader, M. Safta, Constituția României. Decizii CCR, hotărâri CEDO, hotărâri CJUE, legislație conexă, Ed. Hamangiu, București, 2016.

${ }^{96}$ A se vedea M.T. Cicero, Treatise on the Laws [51 BC] (precit.), p. 87. Regula în discuție este prevăzută în Legea celor XII Table.

97 Această exigență derivă în prezent din principiul statului de drept.

${ }^{98}$ Spre exemplu, un alt principiu important de drept natural este principiul proporționalității. In acest sens, a se vedea E. Engle, The History of the General Principle of Proportionality: An Overview, The Dartmouth Law Journal, Vol. X, 2012.

\section{5}


toate acestea, considerăm că ea este suficientă pentru a sublinia importanța dreptului natural în fundamentarea dreptului pozitiv.

\section{Legătura dintre dreptul natural și dreptul penal}

Dreptul penal este mai strâns legat de dreptul natural decât alte ramuri de drept. Această legătură se bazează, în primul rând, pe apropierea dreptului penal de morală99. În al doilea rând, dreptul penal reprezintă unul dintre principalele mijloace de protecție a drepturilor fundamentale, care constituie o componentă substanțială a dreptului natural.

$\mathrm{Cu}$ privire la prima idee enunțată, este necesar să evidențiem pentru început raporturile complexe dintre dreptul natural, morală și dreptul penal, ca ramură de drept pozitiv. Am stabilit anterior în cuprinsul acestei lucrări că dreptul natural cuprinde o sumă de principii fundamentale care decurg din natura umană (cum ar fi libertatea, responsabilitatea, principiul alegerii binelui și evitării răului etc.), precum și reguli vizând protecția drepturilor fundamentale fără de care persoana nu poate funcționa în condiții optime. Reamintim în acest sens că ipoteza clasică de violare a unui drept fundamental presupune încălcarea voinței libere a titularului dreptului în discuție.

\footnotetext{
99 În acest sens, a se vedea I. N. Lungulescu, Drept şi dreptate (precit.), p.117. „Nu mai vorbim de dreptul penal căci el - pentru cine-l citește și pentru cine îl cunoaște, nu este decât o nereușită încercare de a transpune poruncile morale (...) pe portativul multivariat al articolelor de lege”. În același sens, a se vedea J. Moruzi, Studii de drept și procedură penală, București, 1935, p. 138-139. „A ni se afirma, că dreptul în general și dreptul penal în special, este considerat ca fiind refractar, domeniului moralei, înseamnă a exprima un neadevăr”; ,dacă de la dreptul general, trecem la dreptul penal, constatăm că toată istoria lui, nu este, într-o ultimă analiză, decât o luptă puternică spre a readuce fenomenul penal în domeniul moralității”.
}

1036 
Morala cuprinde un set de reguli care stabilesc granița între bine și rău ${ }^{100}$. Dacă avem în vedere această definiție, dreptul natural și morala par să se suprapună în mare parte. Cu toate acestea, în urma clasificării regulilor morale în trei categorii distincte, vom observa că dreptul natural și morala nu se suprapun decât parțial. Astfel, prima categorie de norme morale este compusă din reguli de conduită individuală $\breve{101}^{101}$ a căror încălcare nu prejudiciază alte persoane. Aceste norme vizează forul interior al persoanei, și nu raporturile sale cu ceilalți102. Regulile morale de acest fel nu sunt, de regulă, incluse în dreptul pozitiv, deși sunt, în principiu, conforme dreptului natural, având în vedere că urmăresc scopuri pozitive ce țin de desăvârşirea persoanei. În acest punct, morala şi dreptul natural se întâlnesc în afara dreptului pozitiv.

A doua categorie de norme morale este compusă din reguli de conduită relațională $\breve{103}^{10}$ a căror încălcare prejudiciază direct sau indirect ${ }^{104}$

${ }^{100}$ A se vedea https://www.collinsdictionary.com/dictionary/english/morality, (site accesat în data de 21.04.2020).

${ }^{101}$ T. Avrigeanu, Reflecții asupra valorii sociale ca obiect al ocrotirii penale, R.D.P. nr. 3/1997, p. 74 apud F. Streteanu, Tratat de drept penal. Partea generală, Vol. I, Ed. C.H. Beck, București, 2008, p. 33. În contextul raportului dintre dreptul penal și morală, autorul citat distinge între valori morale de conduită individuală ce țintesc către desăvârşirea spirituală a fiecărui individ în parte (altruismul, virtutea) și valori morale de natură relațională ce interesează în primul rând conviețuirea socială (respectarea drepturilor altor persoane). Autorul consideră că doar valorile din cea de-a doua categorie se pot afla la baza unei incriminări penale.

${ }^{102}$ Ele au ca scop dezvoltarea morală a persoanei și pot include diverse reguli vizând disciplina personală, atitudinea față de viață etc.

${ }^{103}$ T. Avrigeanu, Reflecții asupra valorii sociale ca obiect al ocrotirii penale (precit.), p. 74 apud F. Streteanu, Tratat de drept penal. Partea generală (precit.), p. 33.

${ }^{104}$ Considerăm că în această categorie intră și acele reguli morale, devenite norme penale, care au ca scop principal protecția unor interese publice sau chiar interese ale statului, dar a căror încălcare poate prejudicia în subsidiar și drepturi ale persoanelor. Spre exemplu, infracțiunea

\section{7}


drepturile altor persoane. Violarea acestor reguli presupune adesea ${ }^{105}$, mai ales în cazul infracțiunilor care au ca obiect juridic protecția unor drepturi fundamentale, încălcarea voinței libere a victimelor. Pentru ca regulile de acest fel să devină norme de drept pozitiv, este necesar ca prejudiciul real sau potențial adus altor persoane să prezinte o anumită gravitate. Spre exemplu, simpla minciună, deși influențează negativ relațiile dintre persoane, nu este interzisă de dreptul pozitiv. Pragul de gravitate al prejudiciului este mai ridicat în cazul dreptului penal datorită caracterului său selectiv, dar el există şi în cazul altor ramuri de drept. Astfel, interdicția minciunii nu face obiectul dreptului civil decât în anumite contexte prevăzute de lege ${ }^{106} . \mathrm{Cu}$ atât mai mult, în cazul dreptului penal, minciuna trebuie să atragă consecințe grave pentru a fi transformată în element constitutiv al unei infracțiuni ${ }^{107}$. Se poate astfel observa că regulile de conduită relațională care întrunesc condiția gravității prejudiciului aparțin, în același timp, moralei, dreptului natural

de nedenunțare (art. 266 din Codul penal) vizează în mod direct protejarea interesului public al înfăptuirii justiției. În același timp, comiterea acestei fapte penale poate aduce atingere în mod indirect și dreptului la viață al altor persoane ucise ulterior ca urmare a nedenunțării. În aceeași măsură, și încălcarea unor norme penale care impun o obligație de loialitate față de stat, poate avea în mod indirect consecințe negative asupra drepturilor persoanelor. A se vedea spre exemplu, comiterea infracțiunii de trădare prin ajutarea inamicului - (art. 396 din Codul penal). Acțiunile care intră sub incidența acestei norme pot facilita victoria inamicului, care la rândul său poate recurge la violări sistematice ale drepturilor fundamentale aparținând persoanelor din teritoriul ocupat, existând multe exemple de acest fel în istoria războaielor.

${ }^{105}$ Există și situații în care încălcarea unor astfel de reguli nu presupune violarea voinței libere a victimelor. A se vedea, spre exemplu, infracțiunea de ucidere la cererea victimei sau infracțiunea de act sexual cu un minor. Cu toate acestea, în primul caz, este vorba despre un drept fundamental important la care titularul său nu poate în principiu renunța, iar în al doilea caz este vorba despre protecția unor persoane vulnerabile, al căror discernământ nu este pe deplin dezvoltat, aspect care influențează într-o anumită măsură și posibilitatea acestora de aşi exercita liber voința în domeniul vieții sexuale.

${ }^{106}$ A se vedea, de exemplu, art. 1214 din Codul civil, care reglementează dolul.

${ }^{107}$ A se vedea art. 244 (înșelăciunea) sau art. 273 (mărturia mincinoasă) din Codul penal. 
și dreptului pozitiv, în măsura în care acesta le consacră. Cu privire la dreptul penal, se poate observa că cele mai importante infracțiuni pot fi incluse în această categorie de reguli morale, a căror încălcare presupune atât încălcarea voinței libere a victimelor, cât și întrunirea condiției gravității prejudiciului ${ }^{108}$. În acelaşi timp, subliniem că normele de drept pozitiv care au ca substrat astfel de reguli morale se bucură de un grad ridicat de stabilitate. Ele sunt constante ale dreptului pozitiv şi se regăsesc în majoritatea sistemelor juridice, fiind mai puțin influențate de cultură, chiar dacă îmbracă forme variate în funcție de caracteristicile societăţilor în care se regăsesc.

A treia categorie de norme morale este compusă din reguli de conduită relațională a căror încălcare nu presupune violarea voinței libere a persoanelor implicate în comportamentul interzis. Din acest motiv, se poate constata că nici condiția gravității prejudiciului produs prin comiterea faptei, în calitate de criteriu care să impună reglementarea sa în dreptul pozitiv, nu este întrunită. Consecințele încălcării unor astfel de reguli constau eventual în autodistrugerea morală reciprocă (dar consimțită) a persoanelor în discuție. Regulile de acest tip au un caracter fluctuant ${ }^{109}$, fiind influențate de evoluția (sau involuția) în timp a moralei societății. În realitate, ele nu au ca scop principal protecția persoanei (aceasta e eventual protejată doar în subsidiar şi împotriva voinței sale ${ }^{110}$ ), ci protecția simțului moral variabil al societății. De aceea, normele morale din această categorie intră și ies din sfera

\footnotetext{
${ }^{108}$ Exemple în acest sens ar fi omorul, infracțiunile de violență, furtul, distrugerea, violul etc. Acestea sunt infracțiuni care prejudiciază drepturile fundamentale ale victimei (dreptul la viață, dreptul la integritate fizică, dreptul de proprietate, libertatea sexuală etc.) împotriva voinței sale.

${ }^{109}$ Inclusiv datorită influențelor culturale.

${ }^{110}$ Un exemplu în acest sens ar fi incriminarea prostituției.
}

\section{9}


dreptului pozitiv în funcție de fluctuațiile moralei societățiii"11. Deși unele dintre regulile în discuție aparțin zonei de interferență dintre dreptul natural și morală, ele nu fac parte din nucleul dur al dreptului natural deoarece nu protejează exercitarea voinței libere în domeniul drepturilor fundamentale sau anumite drepturi foarte importante ce trebuie ocrotite chiar împotriva voinței titularului lor. Astfel, prin sintagma nucleul dur al dreptului natural ne referim la acea parte a dreptului natural care trebuie să facă parte din dreptul pozitiv pentru ca acesta din urmă să nu-şi piardă legitimitatea. Nu toate regulile specifice zonei de interferență dintre dreptul natural şi morală trebuie să fie transpuse în dreptul pozitiv. Libertatea individuală devine preeminentă față de moralitate în contextul elaborării acestuia. În măsura în care actele imorale ale individului nu încalcă libertatea altor persoane sau interese sociale bine precizate, educarea morală forțată a acestuia prin intermediul dreptului pozitiv contravine principiului libertății. $\mathrm{Cu}$ rezervele anterior menționate, binele moral nu poate fi ales decât de bunăvoie, iar dreptul pozitiv nu trebuie să aibă rolul de a constrânge individul în acest sens $^{112}$.

\footnotetext{
${ }^{111}$ A se vedea, spre exemplu, tendința de dezincriminare a raporturilor sexuale homosexuale comise în privat în statele vestice.

112 Tentativele de această natură trebuie să rămână în sarcina religiei sau a eticii. Un stat care recurge la norme de drept pozitiv penru a impune persoanelor un cod moral personal nu poate fi decât dictatorial. În acest sens, sunt relevante cuvintele scriitorului C.S. Lewis: „,Dintre toate tipurile de tiranii, o tiranie exercitată în mod sincer spre binele victimelor sale poate fi una dintre cele mai opresive. Poate că e mai bine să trăiești sub dominația unor tâlhari feudali decât sub dominația unor intruși omnipotenți și morali. Cruzimea tâlharului ar putea să se liniștească uneori, lăcomia acestuia ar putea fi săturată la un moment dat; dar cei care ne torturează spre binele nostru, ne vor tortura la infinit, pentru că o fac având aprobarea propriei lor conștiințe". A se vedea C.S. Lewis, God in the Dock: Essays on Theology and Ethics, WM. B. Eerdmans Publishing Co., Michigan, 1970, p. 287-301.
} 
Regulile morale din categoria analizată au pătruns, de-a lungul timpului, şi în dreptul penal, deși în prezent ele nu ocupă o poziție importantă din punct de vedere cantitativ în structura acestuia ${ }^{113}$. Exemple în acest sens ar fi infracțiunile de bigamie ${ }^{114}$, incest, prostituție, proxenetism ${ }^{115}$, precum și incriminarea actelor sexuale consensuale între persoane de acelaşi sex comise în privat ${ }^{116}$. Unele dintre infracțiunile enumerate au fost dezincriminate, datorită faptului că ne aflăm într-o epocă a flexibilizării simțului moral al societății și a promovării drepturilor individuale. Deși unele dintre infracțiunile din această categorie fac parte din dreptul pozitiv, ele nu își au originea în nucleul dur al dreptului natural, care vizează protecția exercitării libere a drepturilor individuale sau protecția anumitor drepturi foarte importante chiar împotriva voinţei titularului lor. În acest punct, există o suprapunere între morală și dreptul pozitiv, care depășește nucleul dur al dreptului natural.

Uneori, ,,morala” societății poate fi chiar contrară dreptului natural. Astfel, au existat situații în care anumite infracțiuni, deşi îşi aveau originea în dreptul natural, nu au fost transpuse în dreptul pozitiv, în virtutea unei „morale” sociale imorale, compusă, de fapt, din prejudecăţi colective discriminatorii. Spre exemplu, în perioada interbelică, violul comis de soț asupra soției nu constituia infracțiune, datorită concepției specifice acelei

\footnotetext{
113 Afirmația este valabilă în contextul sistemelor juridice laice.

114 În varianta în care persoana care încheie o nouă căsătorie are acordul persoanei cu care era căsătorită inițial.

${ }^{115} \mathrm{Ne}$ referim la situația în care determinarea la începerea sau continuarea prostituției nu s-a realizat prin constrângere.

${ }^{116}$ A se vedea art. 200 din Codul penal din 1968.
}

\section{1}


perioade asupra statutului femeii ${ }^{117}$. Totodată, în virtutea aceloraşi prejudecăți discriminatorii, de-a lungul istoriei a fost posibil ca anumite fapte să fie incriminate, deși o astfel de opțiune legislativă era vădit contrară dreptului natural. Spre exemplu, în Statele Unite ale Americii, căsătoria între persoane de rase diferite a fost sancționată penal o lungă perioadă de timp ${ }^{118}$, iar dezincriminarea acestei fapte a avut loc doar în perioada 1948-1967.

Legătura dintre dreptul natural și dreptul penal are totodată la bază faptul că acesta din urmă constituie un mijloc esențial de protecție a drepturilor fundamentale. Astfel, obiectul juridic al unui număr important de infracțiuni este alcătuit din astfel de drepturi, iar cel mai adesea, normele de drept penal în discuție sancționează atingerile aduse acestora împotriva voinței libere a victimelor.

\section{Drept natural vs. drept pozitiv}

În ultima parte a acestei lucrări, urmează să punem în discuție două curente juridico-filosofice contradictorii: iusnaturalismul și pozitivismul juridic.

Înainte de analiza propriu-zisă a celor două curente, vom examina problema eventualelor conflicte dintre dreptul natural și dreptul pozitiv deoarece acest context este cel mai propice pentru a reliefa atât caracteristicile

\footnotetext{
117 A se vedea C.G. Rătescu, H. Aznavorian, I. Ionescu-Dolj, Tr. Pop, I.G. Periețeanu, V. Dongoroz, M.I. Papadopolu, N. Pavelescu, Codul penal Carol al II-lea, Vol. II, Ed. Librăriei Socec \& Co, București, 1937, p. 632, p. 641. Aceeași concepție este pusă în discuție în hotărârea Curții Europene a Drepturilor Omului C.R. c. Marea Britanie (pronunțată în 22 noiembrie 1995, https://hudoc.echr.coe.int, site accesat în data de 22.04.2020).

118 În acest sens, a se vedea I.G. Tragen, Statutory Prohibitions against Interracial Marriage, California Law Review, Vol. 32, 1944, p. 271, p. 280.
}

1042 
dreptului natural, cât și importanța optării la nivel de mentalitate pentru iusnaturalism.

\section{A. Trăsăturile dreptului natural în lumina conflictului cu dreptul pozitiv}

Cele mai evidente conflicte între dreptul natural și dreptul pozitiv pot fi identificate, de-a lungul istoriei, în regimurile politice dictatoriale. În sistemele naziste ${ }^{119}$ şi comuniste, dreptul pozitiv ${ }^{120}$ a contravenit flagrant celor mai elementare principii de drept şi drepturilor fundamentale ale omului, ridicându-se astfel problema soluționării conflictului dintre dreptul natural și dreptul pozitiv ${ }^{121}$.

În acest context, prima trăsătură a dreptului natural identificabilă în urma conflictului menționat este tocmai că acesta își dezvăluie natura mai ales atunci când este violat de normele dreptului pozitiv. În măsura în care cele două tipuri de drept sunt concordante, dreptul natural se reflectă în dreptul pozitiv, constituind o temelie invizibilă a acestuia din urmă. S-a susținut astfel că ,,sunt foarte puține legi care să reproducă o regulă de drept natural, căci scopul legilor nu este de a expune formule abstracte, ci din contră, de a arăta în mod precis și imperativ cum înțelege să rânduiască anumite probleme. Măsurile conținute de legi pot fi în acord cu principiile dreptului natural, fără chiar să le pomenească. Legile cu caracter

\footnotetext{
119 A se vedea L.L. Fuller, Positivism and Fidelity to Law: A Reply to Professor Hart, Harvard Law Review, Vol. 71, No. 4, 1958, p. 648.

${ }^{120} \mathrm{Ne}$ referim atât la anumite legi specifice acestor regimuri, cât şi la practici contrare respectării drepturilor omului.

${ }^{121}$ M. Djuvara, Teoria generală a dreptului, Vol. II, (precit.), p. 398.
}

\section{3}


administrativ sau legile privind drepturile private nu reproduc preceptele dreptului natural. Ele sunt însă indirect inspirate din el, fiind conforme, în fond (...), cu directivele sale" ${ }^{122}$. Pe de altă parte, atunci când există o contradicție vădită între cele două tipuri de drept, „dreptul natural (...) strălucește cu o măreție neobişnuită (...)"123. De aceea, conflictul dintre dreptul pozitiv şi dreptul natural este cel mai important punct de pornire în definirea acestuia din urmă. Doar imperfecțiunile dreptului pozitiv ne fac să aspirăm către dreptul natural sau spre cum ar trebui să fie dreptul. Așadar, pentru a defini dreptul natural, trebuie să pornim de la ceea ce nu îl caracterizează: abuzul, inechitatea, inegalitatea, limitarea disproporționată a drepturilor fundamentale etc. Toate acestea sunt consecințe ale deficiențelor dreptului pozitiv, care, resimțite de destinatarii normelor de drept pozitiv, produc în conștiința acestora o reacție adversă. Această reacție facilitează recunoaşterea dreptului natural prin contrastul dintre acesta şi injustețea dreptului pozitiv ${ }^{124}$. În acest sens, am precizat anterior că dezacordul dintre dreptul natural şi dreptul pozitiv scade gradul respectării voluntare a normelor juridice, situație care conduce la creșterea importanței constrângerii statale pentru asigurarea respectării acestora. La rândul său, constrângerea statală amplifică tensiunea dintre persoane și stat, ajungându-

\footnotetext{
122 I. Rosetti Bălănescu, Dreptul în general și noțiunile sale fundamentale. Expunere introductivă la studiul dreptului, Ed. Ziarului ,Universul”, București, 1937, p. 19-20.

${ }^{123}$ G. del Vecchio, Lecții de filosofie juridică (precit.), p. 344.

${ }^{124}$ I. N. Lungulescu, Drept şi dreptate (precit.), p. 8. În același sens, s-a afirmat că „,violarea unei legi juridice îi dă acesteia un relief mai puternic și face ca adevărul ei să fie și mai profund simţit în sensul său pur ideal. Lezarea dreptului ne dă senzația precisă a naturii sale proprii, deoarece în acest caz se opune dreptului - fără a reuși să-l distrugă sau să-l micşoreze". A se vedea G. del Vecchio, Lecții de filosofie juridică (precit.), p. 194. Sublinierea îi aparține autorului.
}

\section{4}


se, în cele din urmă, la autodistrugerea sistemului de drept pozitiv prin revoluție. Astfel, chiar dacă dreptul natural pare să își ducă existența în mod timid în umbra dreptului pozitiv, se dovedește că aspirațiile către dreptul ideal au aptitudinea de a deveni realitate și de a transforma radical dreptul pozitiv. În cele din urmă, dictaturile odioase sunt succedate de sisteme bazate măcar în parte pe principii de drept natural.

Concluzia anterioară conduce la următoarea trăsătură a dreptului natural, şi anume că acesta este imposibil de distrus prin intermediul dreptului pozitiv ${ }^{125}$. Chiar dacă dreptul natural este redus la tăcere pentru un timp, de un drept pozitiv nedrept, în cele din urmă, primul revine în forță deoarece consacrarea sa juridică este indispensabilă pentru evitarea autodistrugerii societăţiii ${ }^{26}$.

Conflictul anterior expus şi rezultatul acestuia demonstrează obiectivitatea dreptului natural, din care decurge superioritatea acestuia faţă de dreptul pozitiv. Obiectivitatea dreptului natural se traduce în caracterul absolut al acestuia. Ne referim astfel la faptul că nimeni nu poate anula justețea sa prin faptul că o neagă deoarece aceasta se impune de la sine. Spre exemplu, faptul că o persoană ar afirma că atrocitățile din timpul Holocaustului au fost justificate nu poate anula caracterul anormal al celor întâmplate în acea perioadă. Normele dreptului natural nu pot fi știrbite de relativismul concepțiilor. În acest sens, în contextul regimurilor totalitare, un autor sublinia consecințele negative ale relativismului şi necesitatea unor adevăruri obiective şi universale. În opinia sa, dacă nu se recunoaşte

\footnotetext{
125 A.P. D'Entrèves, Natural Law - An Introduction to Legal Philosophy (precit.), p. 22.

${ }^{126}$ Medalion Ayn Rand (precit.), p. 33-34.
} 
caracterul absolut al niciunui adevăr, lipsește fundamentul solid pe baza căruia să poată fi condamnate politicile statelor totalitare ${ }^{127}$.

O altă latură a obiectivităţii dreptului natural constă în faptul că acesta nu are nevoie de confirmări exterioare, de ordin uman, pentru a exista și pentru a-şi îndeplini rolul de fundament al dreptului pozitiv. Dreptul natural este transpus instinctiv în dreptul pozitiv, prin legiferare sau interpretare, inclusiv de către persoanele care nu recunosc existența sa în mod conştient. Această transpunere automată este posibilă datorită faptului că dreptul natural derivă din natura umană.

Superioritatea dreptului natural față de dreptul pozitiv este cea mai importantă caracteristică a acestuia. În absența unui standard care să permită judecarea dreptului pozitiv ${ }^{128}$, orice conținut al acestuia ar putea fi considerat legitim, pe considerente exclusiv formale, indiferent de consecințele negative pe care le-ar produce asupra destinatarilor săi. Superioritatea dreptului natural față de dreptul pozitiv a fost subliniată de numeroși gânditori de-a lungul istoriei. Grațian susținea că dreptul natural are preponderență absolută prin prestigiu asupra cutumei sau legii. Orice normă care a fost recunoscută prin intermediul cutumei sau în scris, trebuie considerată nulă și lipsită de valoare, dacă este în contradicţie față de dreptul natural ${ }^{129}$. Sf. Augustin afirma că o lege nedreaptă nu este lege ${ }^{130}$, iar în concepția lui Toma

\footnotetext{
${ }^{127}$ R. Primus, A Brooding Omnipresence: Totalitarianism in Postwar Constitutional Thought (precit.), p. 427.

${ }^{128}$ În acest sens, a se vedea G. del Vecchio, Lecții de filosofie juridică (precit.), p. 347. Autorul afirmă că dreptul natural e criteriul care permite a judeca dreptul pozitiv și a-i măsura justiția lăuntrică.

${ }^{129}$ A.P. D'Entrèves, Natural Law - An Introduction to Legal Philosophy (precit.), p. 34.

${ }^{130}$ Idem, p. 42-43.
} 
d'Aquino, dacă o lege omenească nu concordă în vreo măsură cu dreptul natural, ea nu mai este lege, ci mai degrabă o denaturare a legii ${ }^{131}$.

Prin opiniile invocate nu dorim să promovăm ideea potrivit căreia orice persoană are dreptul de a refuza să se supună legii, în orice condiții, pe motiv că aceasta este contrară dreptului natural. În acest sens, superioritatea dreptului natural trebuie recunoscută, în primul rând, la nivel principial, chiar dacă efectele practice ale acesteia sunt limitate în sistemele de drept pozitiv din considerente ce țin de securitatea juridică. Prin urmare, cea mai importantă consecință a recunoașterii superiorității dreptului natural față de dreptul pozitiv nu are de-a face cu validarea posibilității de a încălca dreptul pozitiv pe motiv că e contrar dreptului natural, ci constă în schimbarea mentalităţii persoanelor care operează în sistemul juridic. Astfel, o recunoaștere conștientă a superiorității principiale a dreptului natural conferă o legitimitate aparte criticii dreptului pozitiv deoarece persoana care critică realizează că ea însăşi este superioară dreptului pozitiv, din moment ce dreptul natural derivă din natura sa. În consecință, persoana nu există pentru a se supune orbește dreptului pozitiv, ci dreptul pozitiv există pentru a-i garanta drepturile fundamentale derivate din propria sa natură. În măsura în care dreptul pozitiv eşuează în a atinge acest scop, este just să fie criticat prin prisma dreptului natural ${ }^{132}$.

\footnotetext{
${ }^{131}$ Ibidem.

${ }^{132}$ Acest tip de critică este mult mai frecvent utilizat de către persoanele care nu au studii juridice. „Laicii” în domeniul dreptului percep mult mai ușor injustețea dreptului pozitiv prin facultatea înnăscută de a deosebi dreptatea de nedreptate. În cazul juriștilor, această facultate este atrofiată de percepția exclusiv intelectuală asupra dreptului, precum și de resemnarea produsă de conștientizarea faptului că dreptul pozitiv are caracter obligatoriu, indiferent de conținutul său.
}

\section{7}


Totodată, o raportare conștientă la preceptele unui drept natural superior în cadrul criticii aduse dreptului pozitiv are aptitudinea de a deschide noi perspective acestuia din urmă. Dreptul natural este inepuizabil datorită faptului că este compus din valori care pot fi concretizate în practică în modalități infinite. El poate constitui o sursă de inspirație continuă atât pentru crearea unor noi norme de drept pozitiv, cât şi pentru îmbunătăţirea celor existente. Aspirația către dreptul natural va stimula astfel progresul dreptului pozitivi33.

\section{B. Pozitivism juridic vs. iusnaturalism}

Vom începe această secțiune prin a prezenta câteva caracteristici ale pozitivismului juridic. Potrivit curentului în discuție, trăsătura definitorie a legii constă în adoptarea sa în conformitate cu o procedură validă, conținutul acesteia fiind irelevant din perspectiva validității sale ${ }^{134}$. Prin această ruptură dintre formă și conținut, pozitivismul juridic separă dreptul de valorile care iau dat naştere, plecând de la premisa că valorile respective sunt imposibil de

\footnotetext{
${ }^{133}$ În acest sens, a se vedea A. Buciuman, Juridicitatea obligației naturale, Studia Universitatis Babeş-Bolyai - Iurisprudentia, Nr. 3/2015, p. 69. „Necesitatea legitimităţii dreptului pozitiv exprimă o limită a sferei de autonomie a acestuia, dar şi ideea justiției ca finalitate, ca scop ideal spre care trebuie să tindă. În acest ultim sens, nu este suficient ca dreptul pozitiv să nu fie injust, ci, mai mult, el trebuie să reflecte căutarea, mereu deschisă, spre soluţia cea mai justă, pentru că «în interiorul unui sistem de drept pozitiv care nu conține injustiție, există totodată loc pentru o evoluție a dreptului spre reguli şi mai juste» (A. Sériaux, Le droit naturel, P.U.F., $2^{\prime}$ 6d., Paris, 1999, p. 64)”.

134 S.H. Bitensky, The Role of International Human Rights Law and Comprehensive Historical Methodology in Resolving the Conflict between Positive Law and Natural Law Theories, The Journal Jurisprudence, 2013, p. 219. A se vedea și R.L. Hunt, Natural Law v. Positive Law: Interpreting Morality (precit.), p. 239.
}

1048 
cunoscut $^{135}$. Această poziție a condus de-a lungul timpului la o tehnicizare a dreptului, renunțându-se la căutarea a ceea ce este just prin intermediul său${ }^{136}$. Pozitivismul nu recunoaște decât ceea ce poate fi perceput în mod direct prin intermediul simțurilor. El promovează în numele realității un tip de pragmatism juridic, care ascunde adeseori un veritabil cinism cu privire la eventualul conținut al legii. În acest sens, Marx susținea următoarele: ,,ar fi prin urmare o aberație și un nonsens să se creadă că există o normă ideală de drept, un drept natural, o idee de justiție absolută, sau legi nescrise care ar fi superioare dreptului pozitiv. Importantă este doar realitatea ${ }^{137}($...)"138.

Accentul asupra laturii tehnice a dreptului a transformat pozitivismul în curentul juridic predominant la nivelul mentalităţii practicienilor. În acest sens, s-a afirmat că dreptul fiind mai mult pe mâna profesioniștilor, un spirit pozitivist l-a menținut mereu în regiunea fenomenelor ${ }^{139}$. Această abordare a dreptului începe la nivelul educației juridice. Cu privire la acest aspect, Mircea Djuvara observa că „Facultatea de Drept din București este după model francez napoleonian - școală profesională practică, neavând scopul de a împărtăşi știință juridică, ci de a preda arta de a da soluții litigiilor ivite în fața

\footnotetext{
135 A. Buciuman, Juridicitatea obligației naturale (precit.), p. 68. Cu privire la ultima idee enunțată, am arătat deja în cuprinsul acestei lucrări că principiile dreptului natural și drepturile fundamentale (ca parte a dreptului natural) pot fi cunoscute de ființa umană din moment ce ele derivă direct din natura sa. Faptul că dreptul natural are caracter general și trebuie supus unui proces de particularizare pentru a deveni drept pozitiv nu înseamnă că acesta nu poate fi cunoscut în forma sa generală.

${ }^{136}$ Idem, p. 69.

${ }^{137}$ Sublinierea ne aparține.

${ }^{138}$ P. Malaurie, Antologia gândirii juridice, Ed. Humanitas, București, 1997, p. 268.

${ }^{139}$ V.V. Georgescu, Obiect și metodă în interpretarea dreptului - Studiu de metafizică și de logică a juridicității (precit.), Pandectele Române, 1939, p. 41.
}

\section{9}


instanțelor judecătoreşti” ${ }^{140}$. Adevărul acestei afirmații este cu atât mai mult valabil în prezent, la nivelul întregii țări, după 50 de ani de comunism, perioadă în care a dominat un tip de pozitivism juridic radical, specific regimurilor totalitare ${ }^{141}$.

$\mathrm{Cu}$ privire la fundamentul pozitivismului juridic, trebuie menționat că acesta este motivat de teamă. Iusnaturalismul fără limite are aptitudinea de a amenința status quo-ul dreptului pozitiv şi securitatea juridică prin promovarea nesupunerii față de lege. Din același motiv, în domeniul interpretării juridice, pozitivismul urmărește să împiedice interpretările teleologice abuzive prin promovarea interpretărilor literale stricte ${ }^{142}$.

În contrast față de pozitivismul juridic, iusnaturalismul este în primul rând o căutare a esenței dreptului, dincolo de formele sale pozitive. Acest curent corespunde necesității ființei umane „de a cerceta dacă formele existente sunt și juste, dacă autoritatea care comandă, comandă pe drept”"143. În concepția iusnaturalistă, legitimitatea dreptului pozitiv depinde de conformitatea sa cu dreptul natural. Prin urmare, conținutul dreptului pozitiv prezintă mai mare relevanță pentru recunoașterea legitimităţii sale decât adoptarea sa în conformitate cu o procedură validă. Totodată, iusnaturalismul pleacă de la premisa că normele de drept natural pot fi cunoscute prin intermediul conştiinței şi rațiunii umane. În loc să promoveze o abordare

\footnotetext{
${ }^{140}$ M. Djuvara, Fỉlosofia dreptului și învățământul nostru juridic, Pandectele Române, 1942, p. 34-36.

${ }^{141}$ În acest sens, a se vedea R. Mańko, Weeds in the Gardens of Justice? The Survival of Hyperpositivism in Polish Legal Culture as a Symptom/Sinthome, Pólemos - Journal of Law, Literature and Culture, Vol. 7, Issue 2, 2013, (http://ssrn.com/abstract=2277857- site accesat în data de 28.10.2020), p. 218.

${ }^{142}$ L.L. Fuller, Positivism and Fidelity to Law: A Reply to Professor Hart (precit.), p. 669.

${ }^{143}$ G. del Vecchio, Lecții de filosofie juridică (precit.), p. 31.
} 
superficială a dreptului, iusnaturalismul pune în discuție fundamentele normelor juridice, încurajând interpretările ghidate de acestea. Iusnaturalismul nu se resemnează în faţa realităţii concrete; el are ca reper constant starea ideală a dreptului.

$\mathrm{Cu}$ toate acestea, problema principală a iusnaturalismului constă în dificultatea aplicării sale în practică. Din acest punct de vedere, pozitivismul este preferabil, fiind mai uşor de implementat. În acest sens, consecințele juridice practice ale adoptării concepției iusnaturaliste au fost prea puțin discutate în doctrină, motiv pentru care, în cele ce urmează, vom expune succint o variantă de aplicare a iusnaturalismului în două tipuri de sisteme juridice: sisteme în care se respectă principiul statului de drept, respectiv sisteme care aparțin statelor totalitare.

Vom începe cu a doua categorie de sisteme juridice, având în vedere că dezacordul vădit dintre dreptul natural și dreptul pozitiv specific acestor sisteme oferă contextul cel mai adecvat pentru căutarea unui răspuns la următoarea întrebare: este legal ${ }^{144}$ refuzul de a respecta o normă de drept pozitiv vădit contrară dreptului natural? Cu alte cuvinte, atrage conținutul unei astfel de norme nulitatea sa? Înainte de a încerca să oferim un răspuns la această întrebare, vom da câteva exemple de astfel de norme. Așadar, în doctrină s-a afirmat că legislația prin care s-a ratificat retroactiv uciderea a 70 de naziști de către Hitler este vădit contrară dreptului natural145. De asemenea, normele penale cu caracter politic care au fundamentat hotărâri

\footnotetext{
144 În mod evident, nu din perspectiva sistemului juridic contrar dreptului natural.

${ }^{145}$ L.L. Fuller, Positivism and Fidelity to Law: A Reply to Professor Hart (precit.), p. 650.
} 
judecătorești de condamnare în perioada comunistă ${ }^{146}$, decretele de naționalizare ${ }^{147}$ și legislația care permitea supravegherea sistematică a cetățenilor din aceeași perioadă ${ }^{148}$ constituie tot atâtea exemple de violări flagrante ale dreptului natural.

A accepta că normele anterior enumerate sunt valide din punct de vedere juridic ofensează, în primul rând, bunul simț al oricărei persoane rezonabile. În acest sens, ca argumente în favoarea ideii că validitatea unei norme juridice nu poate fi separată de conținutul său, s-au ridicat următoarele întrebări: „Dacă simțim că legea în sine este cel mai sigur refugiu al nostru, oare nu este aşa pentru că inclusiv în cele mai pervertite regimuri, există o anumită ezitare în a transpune cruzimea, intoleranța și lipsa de umanitate în legi? Și nu este clar că însăși această ezitare derivă, nu dintr-o separare a dreptului de morală, ci chiar dintr-o identificare a dreptului cu cerințele morale cele mai imperioase și în mod evident justificate, pe care orice om le poate afirma fără nicio rușine?”"149

În al doilea rând, acceptarea juridicității unor astfel de norme implică automat acceptarea caracterului lor efectiv și obligatoriu150. Această idee

${ }^{146}$ A se vedea M. Lupu, C. Nicoară, Gh. Onișoru, Cu unanimitate de voturi: sentințe politice, Ed. Fundația Academia Civică, București, 1997.

${ }^{147}$ A se vedea Comisia Prezidențială pentru Analiza Dictaturii Comuniste din România, Raport Final, București, 2006, p. 424.

148 C. Anisescu, S. B Moldovan, M. Matiu, "Partiturile” Securitățiii: directive, ordine, instrucțiuni (1947-1987), Ed. Nemira, București, 2007.

${ }^{149}$ L.L. Fuller, Positivism and Fidelity to Law: A Reply to Professor Hart (precit.), p. 637.

${ }^{150}$ Trebuie trasată o diferență între obligativitatea de fapt, care decurge din impunerea unei forțe ilegitime, și obligativitatea juridică. Normele vădit contrare dreptului natural pot fi impuse prin forță, dar ele nu pot fi considerate obligatorii din punct de vedere juridic. Obligativitatea juridică a unei norme nu poate decurge decât din conformitatea sa cu dreptul 
conduce la concluzia că societatea este obligată să se supună unor norme care au ca efect distrugerea persoanelor care o compun, doar pentru că normele în discuție au fost adoptate în conformitate cu o procedură validă. O astfel de poziție este în mod evident absurdă, contravenind instinctului de autoconservare al ființei umane. Totodată, dintr-o perspectivă teleologică asupra dreptului, este inacceptabilă admiterea ideii că acesta poate fi utilizat ca instrument de distrugere al societății.

În al treilea rând, pozitivismul juridic creează un pericol grav. Astfel, concentrarea exclusivă asupra dreptului pozitiv, fără analiza sa critică din perspectiva dreptului natural, deschide cale liberă acelora care doresc să deturneze dreptul de la scopurile sale legitime, datorită docilității celor care sunt orbiți de dreptul pozitiv și consideră că trebuie să i se supună în orice condiții. În acest sens, în doctrină s-a arătat că pozitivismul juridic a reprezentat un factor determinant pentru instaurarea nazismului în Germania. Astfel, în cei 75 de ani anteriori regimului nazist, filosofia pozitivistă a dobândit în Germania un statut pe care nu l-a dobândit în nicio altă țară ${ }^{151}$. Pozitivismul era singura teorie care se putea pretinde a fi „științifică” într-o eră a științei ${ }^{152}$. Acest curent a exclus din știința juridică germană orice interes față de scopurile morale ale legii și față de moralitatea internă a acesteia. De aceea, juristul german era pregătit să accepte ca „lege” orice purta acest nume ${ }^{153}$. Prin urmare, nu este nerezonabil să se afirme că acest curent a contribuit la instaurarea nazismului, având în vedere că Hitler

natural. Nuanțări cu privire la situațiile în care este legitimă nerespectarea dreptului pozitiv contrar dreptului natural vom oferi în cele ce urmează în prezenta secțiune.

${ }^{151}$ L.L. Fuller, Positivism and Fidelity to Law: A Reply to Professor Hart (precit.), p. 658-659. 152 Ibidem.

${ }^{153}$ Ibidem.

\section{3}


nu a dobândit puterea în urma vreunei revoluții violente ${ }^{154}$. Exploatarea formelor legale a început cu prudență, devenind tot mai virulentă pe măsură ce puterea a fost consolidată. Primele atacuri asupra ordinii existente au vizat bastioane ocupate de avocați și judecători. Aceste bastioane au căzut aproape fără nicio luptă 155 .

Prin urmare, nu numai că pozitivismul juridic este inutil în a oferi soluții pentru conflictele vădite dintre dreptul natural și dreptul pozitiv, dar acesta chiar contribuie la consolidarea unui drept pozitiv nedrept. În acest sens, s-au afirmat următoarele: ,dacă tot ceea ce poate oferi școala pozitivistă în vremuri de restriște este observația potrivit căreia oricum ai defini dreptul, acesta este întotdeauna ceva diferit față de morală, învățăturile sale nu ne sunt de mare folos" ${ }^{156}$.

S-ar putea susține că nici iusnaturalismul nu este mai util în astfel de situații, având în vedere că într-un sistem juridic aparținând unui stat dictatorial, concluzia că o normă de drept pozitiv contrară dreptului natural este nulă nu va atrage ineficacitatea normei în discuție. Totodată, refuzul de a respecta o astfel de normă, indiferent că e legal sau nu, poate atrage sancțiuni penale și de altă natură sau chiar moartea. De asemenea, constatarea nulității normei de drept pozitiv contrare dreptului natural poate fi considerată inutilă şi prin prisma faptului că în viitorul sistem juridic conform dreptului natural, vechiul drept nu va mai produce efecte, iar cei care l-au încălcat nu vor fi sancționați, ci dimpotrivă, vor deveni eroi ai noului regim.

\footnotetext{
${ }^{154}$ Ibidem.

155 Ibidem.

${ }^{156}$ Idem, p. 634.
} 
$\mathrm{Cu}$ toate acestea, spre deosebire de pozitivism, care încurajează supunerea oarbă față de un drept pozitiv nedrept, iusnaturalismul are capacitatea de a inspira și de a motiva rezistența față de un astfel de drept. Prin urmare, conștientizarea faptului că dreptul pozitiv în discuție are caracter ilegitim nu va permite persoanelor, şi mai ales juriștilor, să se resemneze și să accepte instaurarea unui regim contrar dreptului natural. În concluzie, considerăm că în sisteme juridice care aparțin unor state totalitare este mai mult decât legitimă nesupunerea față de un drept pozitiv contrar dreptului natural ${ }^{157}$. Iusnaturalismul rămâne, practic, singura șansă de a împiedica instaurarea unui regim totalitar sau de a-l eradica, dacă a fost instaurat deja.

Situația este cu totul diferită în cazul sistemelor juridice în care se respectă principiul statului de drept. În cadrul acestor sisteme, există o conformitate relativă ${ }^{158}$ între dreptul natural şi dreptul pozitiv, care le conferă legitimitate. Caracterul legitim al sistemelor în discuție creează o obligație generală de a respecta dreptul pozitiv, aşa cum este el, fără a invoca imperfecțiunile sale drept scuză pentru a-l nesocoti. În acest sens, considerăm că obligația generală a supunerii față de lege are la bază un principiu fundamental de drept natural, care decurge din natura umană. Principiul supunerii funcționează în diferite tipuri de relații interumane: între părinți și copii, între angajați şi angajatori etc. În aceeaşi măsură, el funcționează în raporturile juridice dintre persoane și stat. $\mathrm{Cu}$ toate acestea, principiul este condiționat de caracterul legitim al autorității care reclamă supunere.

\footnotetext{
${ }^{157}$ Pentru cei care au curajul să o practice

${ }^{158}$ Conformitatea nu poate fi decât relativă deoarece niciun sistem de drept pozitiv nu este perfect, ci doar perfectibil, din perspectiva dreptului natural.
}

1055 
De aceea, considerăm că în sistemele juridice care respectă principiul statului de drept, nu este permisă nesupunerea față de dreptul pozitiv pe motiv că este contrar dreptului natural. O astfel de nesupunere în numele dreptului natural nu ar putea constitui decât o scuză pentru a nu respecta dreptul pozitiv, având în vedere că într-un sistem juridic aparținând unui stat de drept, există remedii ${ }^{159}$ pentru a elimina din sistem normele de drept pozitiv contrare dreptului natural. Invocarea dreptului natural în acest context nu ar putea provoca decât haos și insecuritate. Or, într-un sistem juridic legitim, dreptatea, în sens material, trebuie să cedeze, în anumite situații, în fața ordinii și securităţii juridice. În acest sens, s-a afirmat pe bună dreptate că „o lege, care există în realitate, este lege, chiar dacă nu ne place conținutul său”16o. De asemenea, s-a arătat că ,llegea unui stat (...) nu este un ideal, ci ceva care există în realitate; nu este ceea ce ar trebui să fie, ci ceea ce este"161.

$\mathrm{Cu}$ toate acestea, în pofida necesităţii menținerii unei distincţii nete între dreptul pozitiv și dreptul natural în scopul protecției securităţii juridice, iusnaturalismul nu își pierde utilitatea nici în sistemele care respectă principiul statului de drept. În primul rând, el își păstrează rolul de a motiva, în limitele legii, lupta împotriva normelor contrare dreptului natural. În al

\footnotetext{
${ }^{159}$ Spre exemplu, normele în discuție pot fi eliminate din dreptul pozitiv prin mecanisme apte să conducă la constatarea neconstituționalității lor. În acest sens, considerăm că dreptul natural poate fi invocat prin intermediul principiilor prevăzute în textele constituționale, având în vedere caracterul lor general. Chiar și în situațiile în care remediile de ordin juridic lipsesc, libertatea de a manifesta, precum și exercitarea dreptului de vot, garantate într-un stat democratic, oferă persoanelor posibilitatea de a lupta, cel puțin indirect, împotriva normelor juridice contrare dreptului natural.

${ }^{160}$ H.L.A. Hart, Positivism and the Separation of Law and Morals, Harvard Law Review, Vol. 71, No. 4, 1958, p. 596-597.

${ }^{161}$ Idem, p. 600.
}

\section{6}


doilea rând, raportarea la dreptul natural poate inspira activitatea de legiferare în scopul îmbunătățirii dreptului pozitiv.

$\mathrm{Nu}$ în ultimul rând, iusnaturalismul are aptitudinea de a influența perspectiva asupra interpretării judiciare și modalitatea sa de realizare. Astfel, pozitivismul juridic, prin accentuarea importanței dreptului pozitiv ca drept scris, oferă preeminență metodei literale de interpretare ${ }^{162}$. Din acest punct de vedere, este un fapt general acceptat în doctrină că interpretarea unei norme trebuie să înceapă întotdeauna de la analiza formulării sale lingvistice, acordându-se prioritate sensului literal, dacă norma este clară. O astfel de abordare contribuie la garantarea ordinii și a securităţii juridice, valori ce sunt fundamentale într-un stat de drept. Pe de altă parte, o exagerare a abordării pozitiviste în acest domeniu, manifestată printr-un literalism excesiv, poate conduce la formalism în interpretare. Acesta intervine atunci când metoda literală devine din metoda prioritară singura metodă valabilă de interpretare, făcându-se abstracție de rațiiunea normelor juridice.

Pe de altă parte, iusnaturalismul accentuează importanța valorilor protejate prin intermediul dreptului pozitiv, oferind o poziție semnificativă metodei teleologice de interpretare ${ }^{163}$, fără ca aceasta să însemne ignorarea literei legii. Raportarea la rațiunea normelor juridice, concomitent cu aplicarea metodei literale, poate conduce la interpretări echilibrate, care nu fac exces nici de literă, nici de spirit. Totodată, astfel de interpretări contribuie

\footnotetext{
${ }^{162} \mathrm{Cu}$ privire la influența pozitivismului juridic asupra interpretării a se vedea R. Mańko, Weeds in the Gardens of Justice? The Survival of Hyperpositivism in Polish Legal Culture as a Symptom/Sinthome (precit.), p. 218-219.

163 Totodată, iusnaturalismul poate influența rezultatele interpretării atunci când dreptul pozitiv recunoaște competențe discreționare interpretului. Un exemplu în acest sens ar fi individualizarea judiciară a pedepsei, care oferă interpretului posibilitatea aplicării principiilor echităţii în limitele stabilite de dreptul pozitiv.
}

\section{7}


la efectivitatea normelor juridice. Cu toate acestea, iusnaturalismul în exces poate da naştere arbitrariului în materia interpretării judiciare ${ }^{164}$. În acest sens, s-a observat că teama pozitivismului de interpretări teleologice abuzive nu este lipsită de fundament, considerându-se că fidelitatea față de lege devine imposibilă, dacă nu se acceptă responsabilitățile extinse pe care le implică metoda teleologică de interpretare ${ }^{165}$. Astfel, dreptul natural nu poate fi implementat prin intermediul interpretării decât cu respectarea limitelor impuse de o interpretare literală și sistematică adecvată ${ }^{166}$. Depășirea acestor limite ar antrena, totodată, încălcarea principiului separației puterilor în stat prin transformarea interpretului în legiuitor.

În concluzie, în domeniul interpretării judiciare, pozitivismul şi iusnaturalismul trebuie îmbinate pentru a se ajunge la rezultate echilibrate: interpretări fidele literei legii, dar totodată efective, care în același timp să nu pună în pericol previzibilitatea legii și securitatea juridică.

\section{Concluzii}

La finalul acestei lucrări, considerăm că am reușit să demonstrăm importanța de a opta la nivel de mentalitate juridică pentru curentul iusnaturalist. Chiar dacă unele dificultăţi întâmpinate în sistemele juridice pot fi soluţionate prin abordări pozitiviste, care se rezumă la modificări legislative superficiale, apreciem că doar o mentalitate nouă, care acordă

\footnotetext{
164 În aceeași măsură, și pozitivismul juridic poate da naștere abuzurilor prin intermediul interpretărilor formaliste.

${ }^{165}$ L.L. Fuller, Positivism and Fidelity to Law: A Reply to Professor Hart (precit.), p. 670. 166 Ibidem.
} 
importanța meritată dreptului natural, poate schimba istoria dreptului, motivând actorii lumii juridice să își privească propriul sistem dintr-o altă perspectivă și să lupte pentru schimbarea sa radicală atunci când dreptul pozitiv nedrept ajunge să ocupe un loc ilegitim. 